\title{
Complex Interactions Between Aquatic Organisms and Their Chemical Environment Elucidated from Different Perspectives
}

\author{
Mara E. Heinrichs, Corinna Mori, and Leon Dlugosch
}

\begin{abstract}
Ecosystems form a complex network of interactions regarding energy and material transfers between the living and nonliving environment. Phytoplankton supports all life in the ocean as it converts inorganic compounds into organic constituents. This autotrophically produced biomass presents the foundation of the marine food web. A central part of this food web is the concept of the microbial loop. It describes the prokaryotic degradation and remineralization of organic and inorganic matter and its recycling within the pelagic food web or its return to the nonliving environment. In this review, we describe the composition and functioning of the different compartments of the involved organisms (phytoplankton, prokaryotes, and viruses) and their chemical environment (dissolved organic and inorganic matter) in the ocean, particularly emphasizing their interactions. The aim of this chapter is, therefore, to demonstrate the various ways in which these compartments are connected and how they shape each other. We further emphasize the importance of interdisciplinary research approaches to increase the understanding of the complex interactions within marine ecosystems.
\end{abstract}

\section{Keywords}

Biogeochemical cycling $\cdot$ Microbial loop $\cdot$ Ecosystem functioning $\cdot$ Interdisciplinary research approach . Primary production

\subsection{Introduction}

Few of us may ever live on the sea or under it, but all of us are making increasing use of it either as a source of food and other materials, or as a dump. As our demands upon the ocean increase, so does our need to understand the ocean as an ecosystem. Basic to the understanding of an ecosystem is knowledge of its food web, through which energy and materials flow. (Pomeroy 1974)

An ecosystem is defined as a structural and functional unit of the biosphere, where organisms and the abiotic substances interact with each other to produce and exchange material and energy between the living and nonliving environment (Fig. 15.1). The functional properties of an ecosystem emerge from these diverse interactions. The traditional subdivision comprises four basic constituents: (1) abiotic substances - including organic and inorganic matter, (2) producers - consisting of autotrophic organisms, capable to fix light energy and inorganic nutrients to build up complex organic substances, (3) consumers - consisting of heterotrophic organisms of higher trophic levels, which are able to consume dissolved (DOM) and particulate organic matter (POM), and (4) decomposers - consisting of heterotrophic organisms (e.g., bacteria, archaea) which are able to remineralize organically bound abiotic substances and make them available for the autotrophs (Odum 1959).

A central part of the organic and inorganic matter cycling is the concept of the "microbial loop" (Azam et al. 1983). It describes the trophic pathway in the marine microbial food web where mainly plankton-derived organic matter is recycled by prokaryotes or integrated into the microbial biomass 
Fig. 15.1 Connections

between the different

compartments of the living

(bacteria/viruses and phyto-/

zooplankton) and the

nonliving (DOM/POM and

inorganic matter) environment

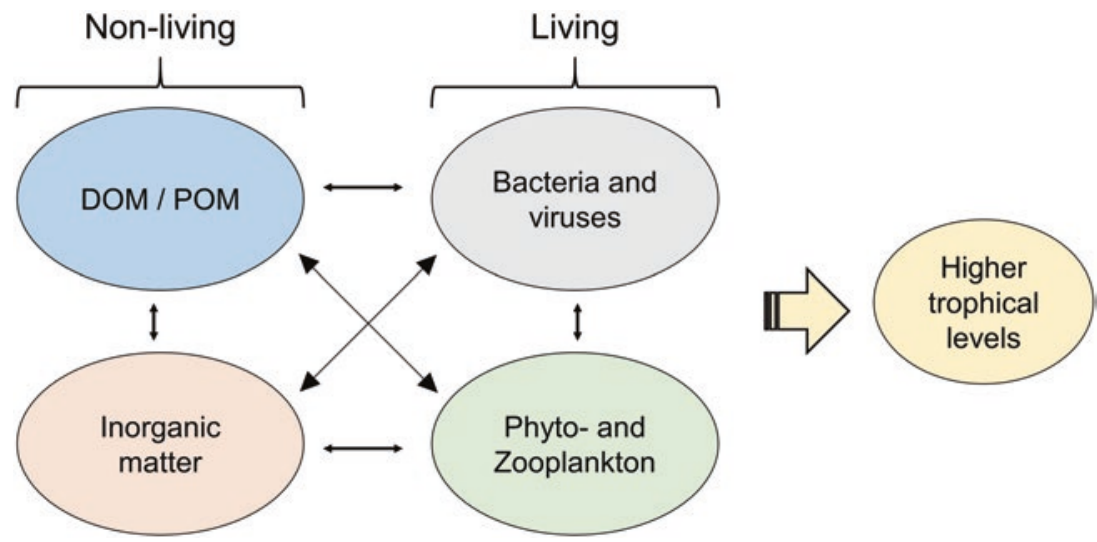

and subsequently either transferred to larger organisms or subjected to continuous recycling (Pomeroy 1974; Azam and Godson 1977; Azam and Malfatti 2007). It is considered to be responsible for the energy and carbon transfer from the DOM pool to higher trophic levels. In this review, the ecosystem will be considered as a complex network of microorganism communities and their environment, interacting as a functional group.

A major part of the nonliving environment is represented by inorganic constituents, which may serve as essential macro- and micronutrients for the living environment (i.e., bacteria and phytoplankton). Nutrient cycling exerts a major control over the overall patterns of primary production in aquatic systems, as it forms the basis for key biological processes, such as the formation of organic matter (Chester and Jickells 2012). In coastal areas, nutrients are mainly derived from processes such as river runoff/erosion, submarine groundwater discharge, glacial weathering, upwelling of nutrient-rich deep water, and atmospheric deposition (Moore 2010; Chester and Jickells 2012). In offshore regions, however, internal microbial recycling is the main control of the nutrient budget in the euphotic zone (Chester and Jickells 2012).

Another major compartment of the nonliving environment is represented by DOM. The global DOM pool contains approximately $662 \pm 32 \mathrm{Gt} C$, a size comparable to the amount of carbon fixed in all living biomass (Hansell et al. 2009; Dittmar and Stubbins 2014). It constitutes one of the largest exchangeable reservoirs of organic carbon in the ocean as it is actively involved in biological processes (Hedges 1992; Hansell and Carlson 2001; Hansell et al. 2009). Due to its enormous size and its importance as substrate, it has a huge ecological significance, playing a central role in marine biogeochemical cycles (Azam et al. 1983; Dittmar and Paeng 2009). DOM is mainly produced by photosynthetic primary production, and it forms the basis of microbial life in the ocean as it supports the metabolic energy demands of carbon and nutrient by heterotrophic marine organisms.
An important fraction of the living environment is represented by phytoplankton. As they are dependent on light and inorganic nutrient supply to perform oxygenic photosynthesis, this pool of primary production is limited to the euphotic zone, which includes the part of the water column where sufficient visible light for photosynthesis penetrates the water body. As primary producers, phytoplankton lives at the interface between the abiotic and biotic realm in the ocean and have a key role in linking both compartments (e.g., Falkowski et al. 1998; Buchan et al. 2014). They represent the basis of the marine food web, supporting most of the heterotrophic production in the ocean as the photosynthetically fixed carbon flows through all other trophic levels (Azam 1998). Moreover, they influence the oceanic chemistry by impacting key biogeochemical cycles, for example, through their involvement in export of carbon and nutrients to the deep sea and by the formation of deep sea sediment through organismic skeletal remains of calcite and opal A (Billet et al. 1983; Nelson et al. 1995; Guidi et al. 2016). They have a global significance for climate regulation due to the fixation of carbon dioxide and generation of oxygen during photosynthesis (Siegenthaler and Sarmiento 1993). Furthermore, some algae species (e.g., Phaeocystis spp.) release the precursor of the climate active gas dimethylsulfide, significantly influencing the sulfur cycle (Charlson et al. 1987; Liss et al. 1994; Archer et al. 2011; Moran et al. 2012).

Bacteria and archaea represent the second key component of the living environment. Their global estimated number even exceeds the amount of stars estimated for our universe (Whitman et al. 1998; Pomeroy et al. 2007). For a long time, members of the domain Archaea were thought to be exclusively restricted to inhabit extreme environments. As cultureindependent studies in more recent years found that archaea can comprise a significant fraction of the bacterioplankton throughout the ocean (Fuhrman et al. 1992; DeLong et al. 1993; Karner et al. 2001), they can considerably contribute to the global element cycles. In this review, we therefore use the term "prokaryotes" inclusive for both, bacteria and archaea. Prokaryotes live in all parts of the ocean, using 
nutrients and energy from diverse sources. Autotrophic prokaryotes use energy in the form of light (photoautotroph) and/or oxidize inorganic nutrients (chemolithotroph) for their energy demands and build up organic matter, which serves as the basis for food webs in diverse ecosystems (Azam et al. 1983; Pomeroy et al. 2007). Heterotrophic prokaryotes, on the other hand, are able to enzymatically decompose and remineralize biomass and make it available again for autotrophs (Azam et al. 1983). Not only bacteria and archaea but also viruses influence the living as well as the nonliving environment. During the last two decades, scientists discovered and described the process of the so called viral shunt (Wilhelm and Suttle 1999), which describes a short cut in the marine food web where viral infections of host cells lead to the release of cellular DOM and POM, which then can be reused by the prokaryotic community. Thus, the viral shunt redirects carbon and energy fluxes from higher trophic levels toward the microbial domain promoting prokaryotic respiration and production on a community level (Fuhrman 1999; Wilhelm and Suttle 1999). As prokaryotic microorganisms represent a large fraction of the marine biomass and are characterized by relatively high active metabolic rates, they are capable of dominating the flux of organic and inorganic matter and create sustained cycles of production, decomposition, and remineralization in the ocean (Pomeroy et al. 2007).

From different scientific points of view, each of the abovedescribed compartments has the potential to be considered to be fundamental for marine life. However, ecosystems are highly interactive systems in which these described living and nonliving compartments exert a controlling influence on the other. They are inseparably linked to each other and none of these compartments is able to stand alone-thus, it is necessary to study them in combined research approaches with scientists from various disciplines to unravel the complex interactions between these compartments. The aim of this review is to emphasize the importance of interdisciplinary research approaches by pointing out fundamental connections between these fields, which are traditionally separated into different subdisciplines. In the following, we will highlight the interconnections between the different compartments of the pelagic ecosystem and emphasize their connections from different scientific point of views.

\subsection{Nonliving Environment}

\subsubsection{Inorganic Components}

\subsubsection{Macronutrients}

Traditionally, nitrogen, silicon, and phosphorus have been regarded as the main nutrient elements in the ocean (Chapman 1986). There are major differences between the three macronutrient cycles in the ocean. Especially, nitrogen cycling forms a complicated web of mainly microbially mediated processes (Chapman 1986; Arrigo 2005). Nitrate and phosphate are essential for a wide range of organisms as they are involved in nutritional processes and are directly incorporated into the soft tissue of autotrophic microorganisms (e.g., via photosynthesis) (Chapman 1986; Arrigo 2005). In contrast, silicon is growth-limiting to a distinct fraction of phyto- and zooplankton (diatoms, silicoflagellates, and radiolarians) and, unlike nitrogen and phosphorous, is involved in the building of hard skeleton parts (Chapman 1986). The assimilation of these macronutrients is mainly dependent on their abundance in the environment and the amount of "cellular machinery" available for their transport into the cell (Arrigo 2005). However, micronutrients (mainly trace metals) are essential to the functioning of this machinery as they are required for the assimilation and transport of macronutrients (Arrigo 2005; Morel and Price 2003).

Nitrogen Nitrogen is considered as the principal limiting nutrient in marine waters (Elser and Hassett 1994; Arrigo 2005). Thus, the human alteration of the global nitrogen cycle has considerable consequences including eutrophication, hypoxia, and harmful algae blooms (Dobson and Frid 2008). Due to its various inorganic species and oxidation states present in the ocean, the nitrogen cycle is often considered as the most complex of the macronutrient cycles. Furthermore, it builds up part of the organic tissue of organism in the form of proteins, amino acids, sugars and enzymes (Aluwihare and Meador 2008; Gruber 2008). By far the largest and least reactive pool of nitrogen is represented by nitrogen gas, which is considered to maintain a constant equilibrium with the atmosphere (Carritt 1954). Other important components of the marine nitrogen pool are (1) fixed inorganic salts, nitrate, nitrite, and ammonium; (2) organic nitrogen species, amino acids, urea, and degradation products of organic matter; and (3) particulate nitrogen (Arrigo 2005). Its cycling and redox chemistry is mainly mediated by phytoplankton and bacterial as well as probably archaeal mediated metabolic pathways and redox reactions (Arrigo 2005) (Fig. 15.2).

Most oceanic phytoplankton species (except for some cyanobacteria taxa) are not capable of direct nitrogen fixation but rely on prefixed nitrogen in the form of dissolved species such as nitrate, nitrite, and ammonium. Thus, the input of nitrogen by in situ fixation and allochthonous sources are important drivers of marine productivity. Most of the nitrogen required for photosynthesis is supplied by internal nutrient cycling in the ocean (Chester and Jickells 2012). The utilization of fixed nitrogen by phytoplankton is limited to the euphotic zone. Part of the organically bound nitrogen is already remineralized by prokaryotes and released back to 


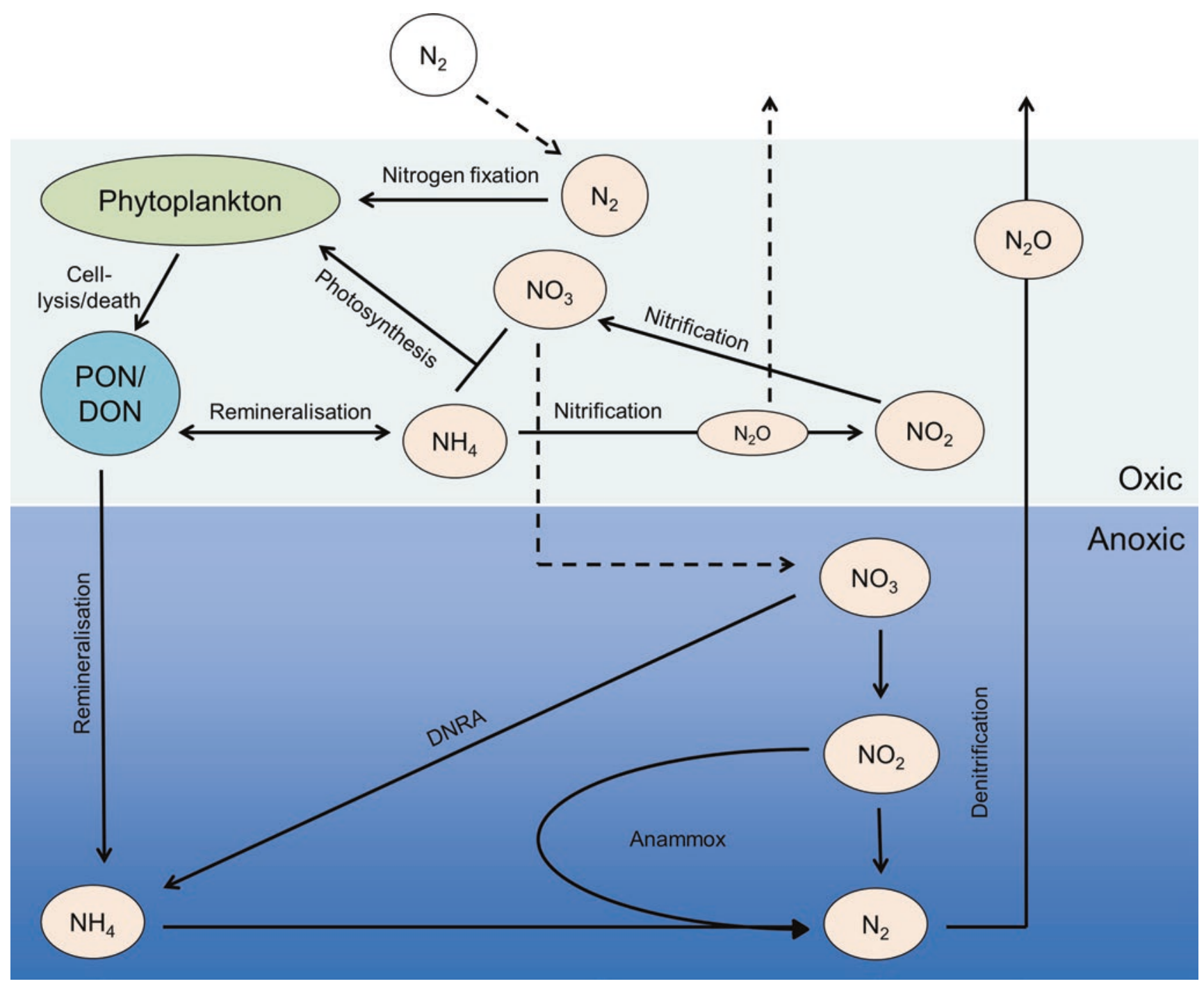

Fig. 15.2 Nitrogen cycle in the upper and lower water column under oxic and anoxic conditions. Chemically and biologically mediated reaction pathways (remineralization, nitrification, dissimilatory nitrate reductase to ammonium (DNRA), anammox, denitrification, nitrogen fixation, and photosynthesis) between the different nitrogen pools (nitrogen gas $\left(\mathrm{N}_{2}\right)$, nitrate $\left(\mathrm{NO}_{3}\right)$, nitrite $\left(\mathrm{NO}_{2}\right)$, ammonium $\left(\mathrm{NH}_{4}\right)$, and nitrous oxide $\left(\mathrm{N}_{2} \mathrm{O}\right)$ ) and their link to the living and nonliving organic matter (dissolved (DON) and particulate organic nitrogen (PON)) are represented by the solid arrows. Dashed arrows implicate transport by physical forcing. Figure produced based on Arrigo (2005) solution within the euphotic zone. The other fraction, particulate organic matter-bound nitrogen, is exported to the deep ocean, where it is subject to continuous prokaryotic degradation. Nitrification, which describes the oxidation of ammonium to nitrite and then nitrate, is mediated by nitrifying bacteria and archaea (see Sect. 15.3.2). The reverse process (denitrification) is carried out by denitrifying microorganisms in anoxic or oxygen-limited environments (e.g., the deep sea, upwelling regions, and highly productive coastal regions). It is considered as the dominant mechanism responsible for the removal of fixed nitrogen from the biosphere and carried out by denitrifying prokaryotes (Arrigo 2005; Chester and Jickells 2012). An intermediate product of these redox reactions is nitrous oxide, which is a greenhouse gas 298 times stronger than carbon dioxide and produced by anoxic prokaryotes during a process called anaerobic oxidation of ammonium (anammox) (Solomon et al. 2007). The final inorganic end product of this prokaryotic mediated redox cascade is nitrate, the thermodynamically stable form of nitrogen in the oxygenated water column (Arrigo 2005).

Phosphorus Unlike nitrogen, phosphorus is not considered as a major limiting nutrient to primary production on a global scale (Paytan and McLaughlin 2007). However, previous studies showed that even if an ecosystem as a whole is limited by nitrogen, certain species within can still be phosphate limited (e.g., Nicholson et al. 2006). Furthermore, in times of anthropogenic pressure and alteration of nutrient cycling, 
especially in the coastal oceans, detailed studies on the marine phosphorus cycle and its role in the marine food web receive more attention (Nicholson et al. 2006; Paytan and McLaughlin 2007). Phosphorus is considered as an important functional as well as structural component, because it is involved in DNA and RNA formation, energy transmission of ATP molecules, and part of cellular components like proteins, lipids, and cell membranes (Paytan and McLaughlin 2007). Thus, its availability not only influences the primary production rates directly in the ocean, but also the species distribution and ecosystem structures (Paytan and McLaughlin 2007). The marine phosphorus pool contains inorganic, organic, and particulate phosphorus. The major fraction $(\sim 87 \%)$ is represented by the dissolved reactive orthophosphate, whereby the relative abundance of the different species is $\mathrm{pH}$ dependent (Paytan and McLaughlin 2007). Marine phytoplankton and autotrophic prokaryotes are able to take up orthophosphate for their metabolic needs (Paytan and McLaughlin 2007). Heterotrophic prokaryotes are mainly responsible for the reverse process; the hydrolysis of dissolved organic phosphorus back to dissolved inorganic phosphorus. While the uptake of orthophosphate is limited to the euphotic zone, the recycling of dissolved organic phosphorus takes place throughout the water column. Nevertheless, the majority of dissolved organic phosphorus is hydrolyzed in the surface layers where it is rapidly taken up by autotrophs and just a small fraction is transferred to the deep ocean (Paytan and McLaughlin 2007). A large fraction of the organic phosphorus pool is considered nonbioavailable as it cannot be taken up into the cell prior to its conversion/hydrolysis to orthophosphate (Cotner and Wetzel 1992). However, in response to phosphate limitation, some phytoplankton species are able to produce specific enzymes, which catalyze the separation of phosphate from organic matter (Cotner and Wetzel 1992). Furthermore, newer studies found a discrepancy in high molecular weight dissolved organic phosphorus concentrations between the mixed and pelagic layer and thus concluded that this pool must be bioavailable on time scales of months to years (Dyhrman et al. 2007).

Another important process, which influences the oceanic reservoir of bioavailable phosphorus, is its burial into marine sediments. Postdepositional processes transform labile phosphorus phases (e.g., adsorbed-, iron-, or organic-bound phosphorus) via amorphous calcium-phosphate phases to diagenetically stable authigenic carbonate fluorapatite (Ruttenberg and Berner 1993; Benitez-Nelson 2000). This process was found in most marine environments and leads to increased burial of reactive phosphorus.

Silicon In the water column, dissolved silicon is mostly present in the form of orthosilicic acid, which is often referred to as silica. Its supply and availability is only crucial for certain families of phyto- and zooplankton such as diatoms and radiolarians, which require silica for their opal shell formation (Ragueneau et al. 2000). Thus, silica availability is an important factor in regulating the species composition, but not necessarily the overall productivity in the euphotic zone (Ragueneau et al. 2000). However, especially in coastal waters, silicon limitation induced by eutrophication or riverine input has important consequences for the functioning of the ecosystem. Several studies documented a shift from siliceous phytoplankton to less desirable planktonic organisms (e.g., harmful algae blooms) due to a disrupted silicon supply and budget (e.g., Conley et al. 1993; Heisler et al. 2008). The fate of the biogenic opal produced in the euphotic layer is controlled by physical, chemical, and biological factors, which mediate the competition between the export and recycling in the surface waters (Ragueneau et al. 2000). Since the ocean usually is undersaturated with respect to the biologically formed opal A (siliceous ooze), the biogenic silica from the skeletal parts of the organisms is released back into the water column by simple physical dissolution without any prokaryotic involvement. However, as the coating of opal by biological material (e.g., residual cell membranes) is known to inhibit its dissolution, even this chemical process is mediated by prokaryotes (Ragueneau et al. 2000). The fraction of the biogenic opal which is not remineralized finds its final fate in the diagenesis of opal A via opal-CT (porcelanite) to chalcedony or cryptocrystalline quartz (chert) (Kastner et al. 1977; Williams et al. 1985).

\subsubsection{Micronutrients}

Even though most ecological studies focus on macronutrient cycling, there are several elements (e.g., manganese, iron, molybdenum, cobalt, nickel, copper, zinc, and cadmium), which are known to be biologically active. They can be (co-) limiting as they catalyze macronutrient uptake and transformation processes (e.g., species transformation within the nitrogen cycle) as cofactors or part of cofactors in enzymes (e.g., nitrogenase) (Fig. 15.3). As part of proteins, they are able to influence the productivity and shape planktonic and prokaryotic communities (Sunda 1989, 1994; Morel and Price 2003; Arrigo 2005; Twining and Baines 2013). As a result of the planktonic uptake, most of the essential trace metals (except for manganese, molybdenum, and nickel) are depleted in the surface ocean and show the typical nutrienttype element distribution along the water-column (Bruland and Lohan 2003). These concentration profiles are the result of a steady downward flux of mainly planktonic biomass, which is balanced by an advective/diffusive upward flux of prokaryotic recycled elements (Bruland et al. 2013). Most of the small plankton ( $<2 \mu \mathrm{m}$; mainly picoplankton) is already decomposed by heterotrophic prokaryotes in the surface waters and, along with formerly organically bound nutrients 


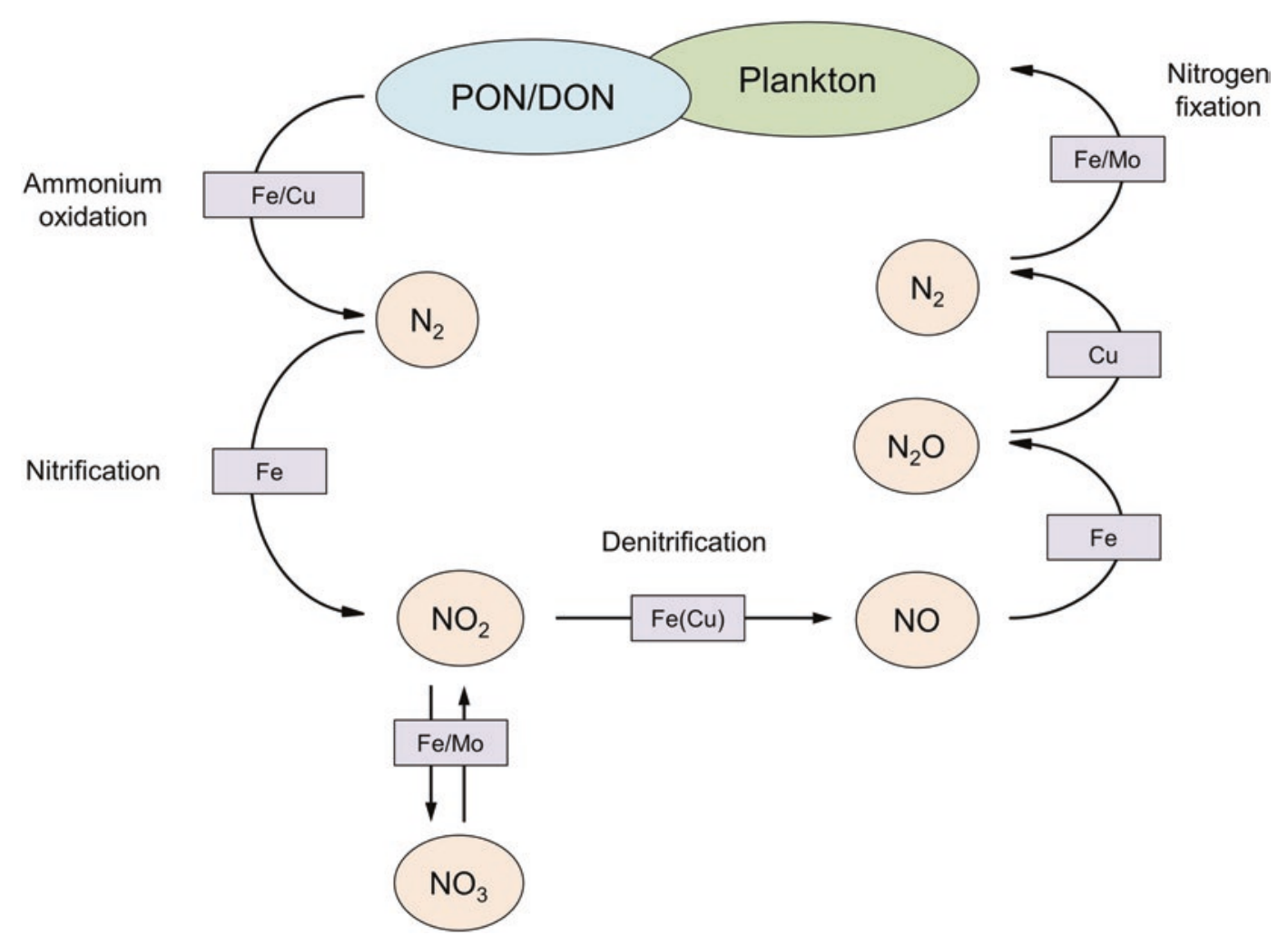

Fig. 15.3 Nitrogen cycle, illustrating the cycling of particulate (PON) and dissolved organic nitrogen $(\mathrm{DON})$, nitrite $\left(\mathrm{NO}_{2}\right)$, nitrate $\left(\mathrm{NO}_{3}\right)$,

and trace metals, released back into solution (Morel and Price 2003).

The uptake of trace metals by prokaryotic microorganisms is dependent on the metal's chemical speciation. As not all essential trace metals (iron, cobalt, copper, zinc, and cadmium) are present in a bioavailable form, microorganisms developed mechanisms to make them available or rather adjust their environment according to their specific needs (Morel and Price 2003; Sunda 2012; Boyd et al. 2017). Prokaryotic microorganisms are able to release chelators, which are complexing agents (e.g., siderophores and cobalophores) that break bonds of, for example, organic matter and transfer trace metals to accessible forms (Maldonado and Price 2001; Saito et al. 2002). Culture studies showed that some cyanobacteria are able to release, for example, copper and cadmium, complexing agents to detoxify their environment (Moffett and Brand 1996). Besides being the object of strong organic/biogenic ligand binding, trace metals are present in several oxidation states and are thus involved in dynamic redox cycling. To access trace metals, which would be otherwise nonbioavailable, some plankton species are actively involved in these redox transformation processes. A prominent example for microbiological-mediated redox transformation is the oxidation of manganese (II) by a number of prokaryotes via extracellular copper oxidase (Francis nitrous oxide $\left(\mathrm{N}_{2} \mathrm{O}\right)$, and nitric oxide $(\mathrm{NO})$ and the involved metal cofactors in each enzymatically catalyzed step. Produced based on Morel and Price (2003)

and Tebo 2001; Tebo et al. 2004). Furthermore, there have been comprehensive studies on the microbial use of manganese oxides as an alternative electron acceptor during the early diagenesis in sediments (Burdige 1993). Another prominent example is the enzymatically catalyzed extracellular reduction of iron(III) from complexes such as siderophores by the diatom Thallassiosira oceanica (Maldonado and Price 2001). These examples show that the interaction between trace metals and planktonic, bacterial, and archaeal microorganisms are reciprocal. As trace metals are part of essential microbial processes (e.g., macronutrient uptake and photosynthesis), they are able to influence the productivity as well as community composition. In turn, the microorganisms have a profound effect on the chemistry and cycling of these metals in the ocean.

\subsubsection{Dissolved Organic Matter}

\subsubsection{Composition and Biogeochemical Cycling of DOM}

Operationally defined as the fraction of organic matter that passes through filters with nominal pore sizes of $0.2-0.7 \mu \mathrm{m}$ (Ogawa and Tanoue 2003), DOM is a highly complex mixture and is mainly composed of reduced carbon, oxygen, and 
hydrogen bound to heteroatoms such as nitrogen, phosphorus, and sulfur (Hansell 2013; Repeta 2015). The presence of these elements substantiates the role of DOM as nutrient and energy source for marine organisms and its involvement in many biological processes such as photosynthesis and respiration. By binding a wide range of bioactive trace metals along with various other trace elements (e.g., manganese, iron, copper) onto its colloidal fraction, DOM further plays a role in the biogeochemical cycling and the availability of trace metals (Aiken et al. 2011; Sunda 2012). These metalcolloid complexes can influence the biological production of the ocean by affecting the growth and species composition of marine phytoplankton (Sunda 1989, 1994).

Most of marine DOM is formed in the euphotic zone of the ocean by photosynthetic primary production at an annual rate of approximately $50 \mathrm{Gt} \mathrm{C}$ (Behrenfeld and Falkowski 1997; Carlson 2002). A major part of the fixed carbon is respired, while the remaining fraction is either incorporated by organisms of higher trophic levels, and thus transformed to POM, or enters the DOM pool via a variety of processes (Fig. 15.4). A common mechanism of algae to produce DOM is the extracellular release (e.g., Wetz and Wheeler 2007; Thornton 2014) by which about $20 \%$ of the photosynthetically fixed carbon can be excreted from actively growing algae cells (Mague et al. 1980; Maranon et al. 2005). A number of other processes are furthermore responsible for the production of DOM including viral and microbial-mediated lysis, natural decay of cells (Wilhelm and Suttle 1999; Martin 2002), herbivore grazing (e.g., by sloppy feeding; Nagata and Kirchman 1992), or the transformation of POM (Azam and Malfatti 2007; Smith et al. 1992).

The production and consumption of DOM is tightly coupled in the surface of the oceans. As the basis of the microbial life in the ocean, DOM supports the demands of

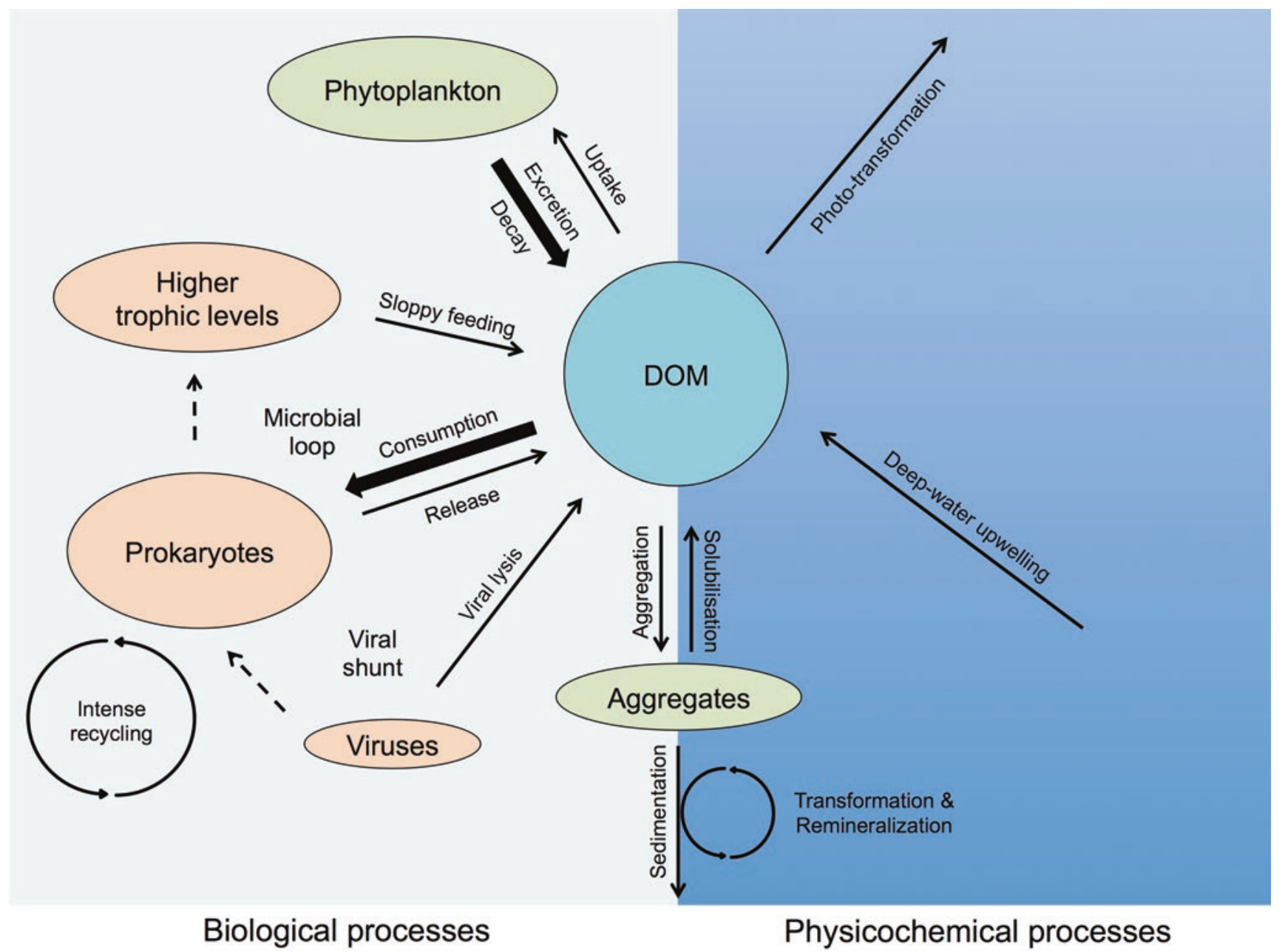

Fig. 15.4 Schematic representation of the fate of DOM in the ocean. Arrows indicate the various production (arrowhead pointing toward DOM pool) and removal processes of DOM (arrowhead pointing away), while the dashed arrows represent dominant biological processes involved in the transfer of DOM. Due to these processes, the fraction of labile DOM decreases rapidly with depth, whereas the refractory character of the DOM pool considerably increases during its export to the deep ocean. Produced based on Carlson (2002). DOM, dissolved organic matter. 
heterotrophic prokaryotic microorganisms for metabolic energy, carbon, and nutrients. Prokaryotes play a central role in the cycling of DOM within the microbial loop (Azam et al. 1983; Pomeroy et al. 2007; Logue et al. 2016). Additionally, also marine eukaryotes can directly utilize certain compounds of the DOM pool, though they make up a relatively small proportion of DOM consumption relative to heterotrophic prokaryotes (Michelou et al. 2007; First and Hollibaugh 2009; Flynn et al. 2013).

\subsubsection{Bioavailability of DOM}

DOM represents a continuum regarding biological availability from very labile to highly inaccessible material. Based on its residence time and thus reactivity, DOM can be classified into five categories:

Labile DOM includes highly bioreactive compounds such as amino acids, short-chain organic acids, vitamins, and easily hydrolyzable biopolymers such as proteins or homopolysaccharides. Prokaryotic microorganisms rapidly turn over these compounds in the surface ocean within hours or days after production (Teeling et al. 2012; Buchan et al. 2014). Low molecular weight material (<600 Da) can be directly taken up through the prokaryotic cell membrane, while high molecular weight compounds have to be hydrolyzed by extracellular enzymes prior to uptake (Weiss et al. 1991; Carlson et al. 2007; Arnosti 2011). The high demand of prokaryotes for organic substrate and nutrients keep steady-state concentrations of labile DOM constituents exceedingly low with a global pool of $<0.2 \mathrm{Gt} \mathrm{C}$ (Hansell 2013).

Semi-labile DOM is resistant to rapid utilization by microbes, thus residing longer in surface waters compared to very labile material. It is turned over within months to several years within the upper mesopelagic zone and forms, together with the labile DOM fraction, the basis of the marine food web (Carlson et al. 2004).

Semi-refractory DOM accumulates in mesopelagic zones (500-1000 m), where it is turned over in decades to centuries (Hansell et al. 2012).

About one third ( 16 Gt C) of the freshly produced DOM is resistant to microbial degradation and is exported from the upper water column to the deep sea, where it accumulates in the refractory DOM pool with a global inventory of $630 \mathrm{Gt}$ C (Falkowski et al. 1998; Jiao et al. 2010; Hansell and Carlson 2013).

The most stable pool of DOM is the ultra-refractory fraction amounting to $>12 \mathrm{Gt} \mathrm{C}$ and accounting for $\sim 2 \%$ of the concentration of bulk dissolved organic carbon (DOC) in the deep sea (Dittmar and Paeng 2009; Hansell 2013).

Average radiocarbon ages between 4000 and 6000 years and a mean residence time of several thousands of years, until its reintroduction into the surface ocean via ocean circulation, already indicate the limited reactivity and slow cycling of deep sea DOM (Williams and Druffel 1987; Bauer et al. 1992). Mean concentrations of DOC in surface waters vary between 60 and $90 \mu \mu \mathrm{mol} \mathrm{L} \mathrm{L}^{-1}$, while the concentrations of deep sea DOC are uniformly low ranging from 35 to $45 \mu \mathrm{mol} \mathrm{L}{ }^{-1}$ (Ogawa and Tanoue 2003). The stoichiometric ratio of $\mathrm{C}: \mathrm{N}: \mathrm{P}$ in DOM is depleted in nitrogen and phosphorus in comparison to the average marine phytoplankton composition of C:N:P = 106:16:1 (Redfield et al. 1963) with an elemental relationship of $\mathrm{C}: \mathrm{N}: \mathrm{P}=300: 22: 1$ in surface waters and even more depleted with $\mathrm{C}: \mathrm{N}: \mathrm{P}=444: 25: 1$ in deep water DOM (Benner 2002). This indicates the preferential consumption of nitrogen- and phosphorus-rich compounds within the DOM pool and a more degraded status of DOM in deeper water relative to the diagenetically younger surface DOM.

Some biotic and abiotic mechanisms are attributed to be potential processes for the generation of biologically inaccessible DOM, such as the production by prokaryotic microorganisms (Ogawa et al. 2001; Jiao et al. 2010; Lechtenfeld et al. 2015; Osterholz et al. 2015), photochemical reactions (Mopper et al. 1991; Benner and Biddanda 1998; Rossel et al. 2013), or heat-induced condensation processes (Dittmar and Paeng 2009; Rossel et al. 2015). Abiotic processes like sorption onto particles (Druffel et al. 1996), thermal decomposition (Lang et al. 2006; Hawkes et al. 2015), and incorporation into marine aerosols (Kieber et al. 2016) are proposed as removal mechanisms of refractory DOM. Furthermore, photochemical processes can remove biologically resistant DOM (Stubbins et al. 2010) but was found to also transform refractory to bioavailable compounds leading to further microbial utilization (Kieber et al. 1989; Mopper et al. 1991; Benner and Biddanda 1998; Gonsior et al. 2014; Medeiros et al. 2015a).

Despite the importance of DOM as substrate for prokaryotes, it is still an enigma why DOM persists in the ocean over these long time spans without being degraded by prokaryotes. Current hypotheses about the recalcitrance of DOM are summarized by Dittmar (2015). Either environmental factors such as lack of essential metabolites or electron acceptors could hinder the microbial decomposition. Furthermore, specific molecular structures may be difficult to assimilate or metabolize by prokaryotic microorganisms. Due to its huge compositional and structural diversity, individual DOM compounds could be present at too low concentrations (Koch et al. 2005; Hertkorn et al. 2013), limiting an efficient assimilation of energy and processing by prokaryotes (KovarovaKovar and Egli 1998; LaRowe et al. 2012; Stocker 2012; Arrieta et al. 2015).

\subsubsection{Biological Imprint on the DOM Composition}

All production, removal, and transformation processes leave an imprint on the composition of DOM and influence both, 
the ecological and biogeochemical significance of the resulting DOM compounds. Phytoplankton communities synthesize and excrete hundreds of different organic compounds in the surrounding water (Becker et al. 2014; Bittar et al. 2015; Longnecker et al. 2015; Medeiros et al. 2015b). The chemical composition and concentration of phytoplankton-derived DOM is highly variable and depends on the growth stage of the cells (Myklestad 1974; Carlson et al. 1998) as well as the producing taxa or nutrient availability (Fuhrman et al. 2008). Therefore, DOM represents a highly diverse substrate for the prokaryotic populations. The huge molecular diversity of the DOM pool is further intensified by subsequent prokaryotic production and transformation processes (Grossart et al. 2006; Rink et al. 2007; Lechtenfeld et al. 2015), making DOM one of the most complex molecular mixtures on Earth with possible hundreds of thousands of different molecules (Dittmar and Stubbins 2014; Zark et al. 2017). The chemical diversity of DOM is reflected by the phylogenetic diversity as well as the metabolic versatility and potential, which is encoded in marine microbial communities (Becker et al. 2014). Both compartments are deeply interconnected and shape the composition of each other (Alonso-Sáez et al. 2012; Kujawinski et al. 2016).

\subsection{Living Environment}

\subsubsection{Phytoplankton}

The importance of phytoplankton is beyond question. (Reynolds 1984)

\subsubsection{Diversity and Ecological Function(ing) of Phytoplankton}

In general, plankton is defined as free-floating, unicellular organisms or colonies of organisms that are suspended in the water column. The term phytoplankton underlies no systematic concept, but is rather functionally defined by the ability to synthesize complex organic biomass using inorganic matter and solar energy via oxygenic photosynthesis (Buchan et al. 2014).

Phytoplankton is an extremely diverse polyphyletic group, including both prokaryotic and eukaryotic species (Sournia et al. 1991; Falkowski and Raven 2007). Diatoms, dinoflagellates, and coccolithophorides are among the most prevalent eukaryotic phytoplankton taxa, contributing significantly to the bulk diversity of phytoplankton communities (Simon et al. 2009). Bloom-forming diatoms are globally distributed and often predominant in temperate waters of higher latitudes, accounting for up to $40 \%$ of the total primary production in the ocean (Nelson et al. 1995; Brzezinski et al. 1997; Armbrust 2009). All species are covered by bivalved frustules made of biogenic opal A (see Sect.
15.2.1.1) that increases the density of the cells. Thus, diatom abundance is dependent on mixing conditions that keep them in the euphotic zone of the water column, and the availability of silicate for the construction of their shells (Armbrust 2009; Amin et al. 2012). Unicellular dinoflagellates have the ability of active swimming owing to their two flagella and mixotrophic lifestyle, which contributes to their success in the ocean (Smayda 1997; Smayda and Reynolds 2003). Coccolithophores produce external shells composed of calcium carbonate plates and have therefore an influence on the ocean's alkalinity and carbon budget (Archer et al. 2000). The most abundant species in the contemporary ocean is Emiliania huxleyi, which is known to form enormous blooms, thus representing an important source of biologically produced calcite (Westbroek et al. 1989; Brown and Yoder 1994). An impressive example is the formation of the white chalk cliffs of the island of Rügen in the Baltic Sea by fossil coccoliths (Hjuler and Fabricius 2009).

Prokaryotic picoplankton is almost exclusively represented by the unicellular Cyanobacteria genera Synechococcus and Prochlorococcus (Partensky et al. 1999). They are abundant and widespread in many ocean regions, contributing considerably to marine primary production due to their ability of efficient nutrient and light acquisition and their high adaptability to different environmental conditions (Moore et al. 1995; Flombaum et al. 2013; Biller et al. 2015; Callieri 2017).

Although phytoplankton biomass accounts for only $1 \%$ of the biomass of all photosynthetic organisms on earth, they are responsible for roughly half of the global net primary production with 45-50 Gt C per year (Longhurst et al. 1995; Antoine et al. 1996; Field et al. 1998). About half of the fixed carbon is directly processed by heterotrophic prokaryotes (Cole et al. 1988; Ducklow et al. 1993). The remaining carbon either enters the classic marine food web or is transported from surface waters to the deep ocean as sinking particles via the biological pump (Fig. 15.5) (Eppley and Peterson 1979; Passow 2002; Amin et al. 2012). During export, the aggregates are colonized by prokaryotes and subject to transformation, i.e., microbial remineralization, adsorption or desorption processes leading to nutrient regeneration (Smith et al. 1992).

\subsubsection{Spatial and Seasonal Effects on Primary Production}

Marine net primary production varies over a wide range of time scales including tidal, daily, and seasonal cycles as well as decadal oscillations (Behrenfeld et al. 2006; Cloern and Jassby 2010; Chavez et al. 2011). Abundance and composition of phytoplankton, and thus the annual cycles of primary production, are influenced by various physical, chemical, and biological factors. Nutrient limitation (bottom-up regulation), grazing, and parasitism by prokaryotes and viruses 


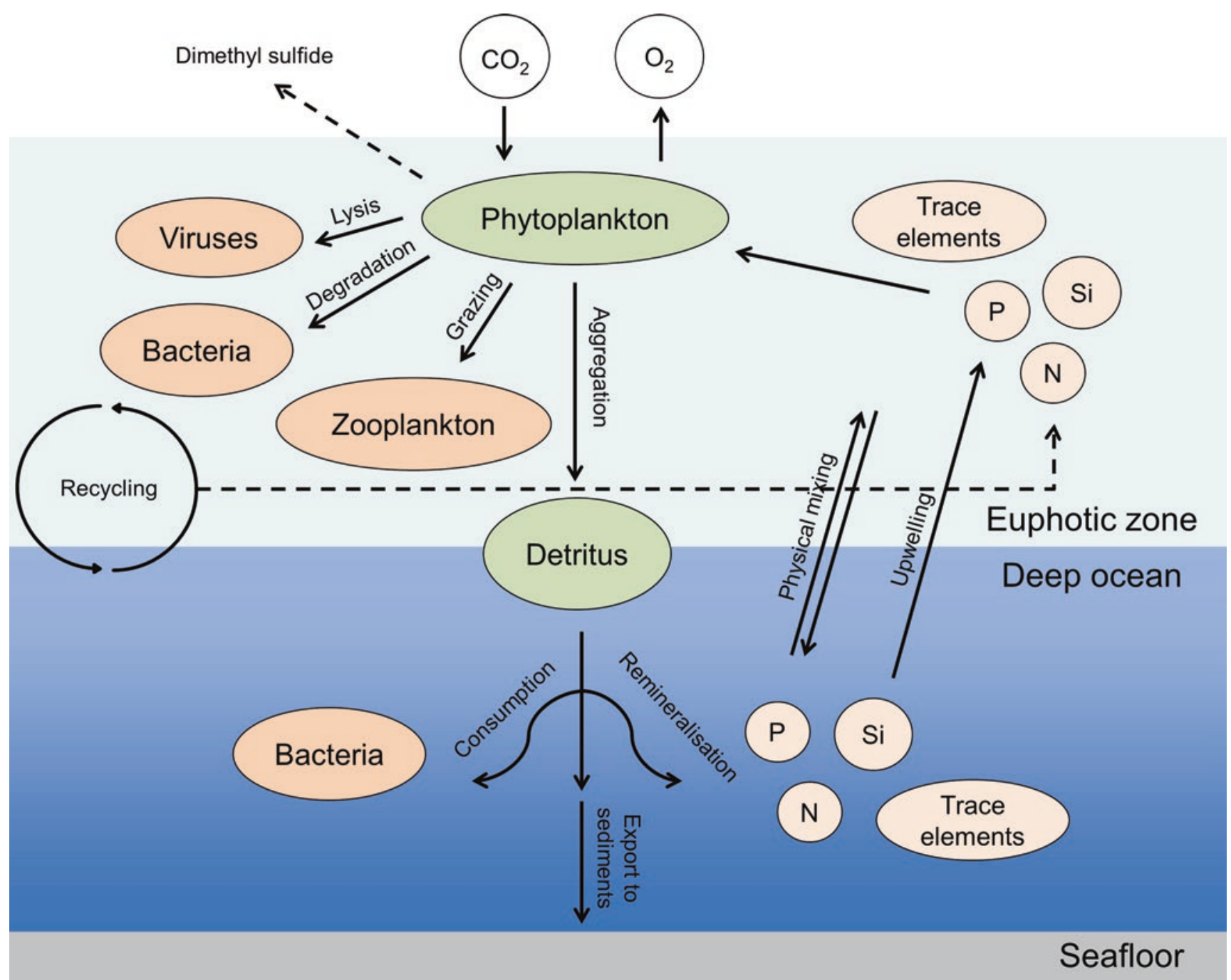

Fig. 15.5 Overview of the role of phytoplankton on various compartments of the marine environment including the atmospheric gas composition, inorganic nutrients, and trace element fluxes as well as the transfer and cycling of organic matter via biological processes. The photosynthetically fixed carbon is rapidly recycled and reused in the surface ocean, while a certain fraction of this biomass is exported as sinking particles to the deep ocean, where it is subject to ongoing transformation processes, e.g., remineralization. Figure based on references in the text

Pennington et al. 2006). Hence, tropical regions are characterized by low rates of primary production and intense nutrient recycling of the permanently nutrient-limited phytoplankton (Pennington et al. 2006). Picoplankton such as Prochlorococcus spp. dominate the phytoplankton biomass in these oligotrophic zones (Landry and Kirchman 2002; Reynolds 2006) due to their relatively high surface to volume ratios, which is an advantage to more efficiently exploit resources at low nutrient concentrations (Chisholm 1992; Flombaum et al. 2013; Biller et al. 2015).

At higher latitudes, typically two annual bloom events are observed, namely, in autumn and during the transition from winter to spring (Pennington et al. 2006). In winter, nutrients become replenished in the upper water, due to intense mixing of the water body and erosion of the thermocline by wind 
and cooling (e.g., Sommer and Lengfellner 2008). The combination of increasing light intensity, higher sea surface temperatures, and high nutrient concentrations, but low grazing pressure in early spring allow the phytoplankton to develop high cell densities (Lessard et al. 2005; Smetacek and Cloern 2008; Behrenfeld 2010; Taylor and Ferrari 2011). Phytoplankton blooms last from several weeks to months and are accompanied by a succession of different phytoplankton species as well as grazers, prokaryotes, and viruses (Riemann et al. 2000; Yager et al. 2001; Chang et al. 2003; Loeder et al. 2011; Teeling et al. 2012). Diatoms account for most of the net primary production during spring blooms in the cold and nutrient-rich waters of higher latitudes, as they have both high nutrient uptake and growth rates (Chisholm 1992; Litchman et al. 2006). Because of their large size, the density of their skeleton, and the tendency to form aggregates, they significantly contribute to the export of organic matter to the deep sea and loss of nutrients bound in their biomass (Smetacek 1985; Riebesell 1991; Smetacek 1999; Armstrong et al. 2002; Amin et al. 2012). During summer, intense nutrient recycling occurs and the autotrophic community is mainly dominated by dinoflagellates, which are better adapted to the present conditions. Falling temperatures and increasing storm events in autumn destabilize the thermal stratification of the water column resulting in the upwelling of nutrients to the surface. The still sufficient light intensities in combination with the nutrient input allow a second blooming event of mainly diatoms and dinoflagellates, before conditions become unfavorable for photosynthesis in winter.

During a bloom event, the release of photosynthetically produced organic compounds by autolysis of dead, decaying, and healthy cells (extracellular release, see Sect. 15.2.2) to their surroundings fills up the DOM and POM pool and provides a wide range of substrate, which is readily assimilated by prokaryotes (Fogg et al. 1965; Myklestad 2000; Arnosti 2011; Kujawinski 2011; Teeling et al. 2012; Buchan et al. 2014). The chemical composition and concentration of the phytoplankton-derived material depend and considerably shape the composition and fate of the organic carbon pool (see Sect. 15.2.2; Bjørrisen 1988; Biddanda and Benner 1997). The interactions between prokaryotes and plankton are quite complex and have evolved over evolutionary time scales, ranging from commensalism to parasitism (e.g., Amin et al. 2012; Lima-Mendez et al. 2015; Seymour et al. 2017). Not only prokaryotic microorganisms depend on phytoplanktonic primary production such as DOM as substrate, but they also support the growth of autotrophs by the provision of nutrients via recycling (Azam et al. 1983) or fixation of nitrogen (Foster et al. 2011), the synthesis of vitamins (Kazamia et al. 2012), or the detoxification of metabolic byproducts (see Sect. 15.2.1.2; Hünken et al. 2008). However, prokaryotes can also compete with phytoplankton for limited essential nutrients, which can manifest in the direct lysis of phytoplankton cells or the production of algicidal and antimicrobial molecules, respectively (Amaro et al. 2005; Seyedsayamdost et al. 2011; Cude et al. 2012; Bertrand et al. 2015). The form of interaction also depends on the environmental conditions, e.g., the nutrient availability (Danger et al. 2007).

\subsubsection{Nutritional Requirements and Elemental Stoichiometry}

Major nutrients (i.e., nitrogen, phosphorus, and silicate for silicified diatoms and silicoflagellates) and trace elements (e.g., iron, cobalt, zinc, nickel, selenium) are required for phytoplankton growth as they are integral parts of phytoplankton biomass and are involved in various internal processes (see Sect. 15.2.1; Morel 1986; Lessard et al. 2005; Schoemann et al. 2005; Twining and Baines 2013). Both compartments, plankton and nutrients, influence each other (e.g., Sunda 2012). Bio-limiting nutrients (nitrogen, phosphorus, and iron) can regulate community structures and restrict phytoplankton biomass and productivity by influencing both the initiation and termination of bloom events (Boyd et al. 2000; Sunda 2012). Plankton, on the other hand, can influence the concentration, redox chemistry, and the biogeochemical cycling of major and trace metal nutrients (Morel 2008; Sunda 2012). As well as prokaryotes, phytoplankton is able to actively shape its trace element environment toward its needs by the release of metal binding chelators for detoxification or trace metal uptake (see Sect. 15.2.1.1; Moffett and Brand 1996; Hutchins et al. 1999; Sunda 2012).

The canonical Redfield ratio (see Sect. 15.2.2; Fleming 1940; Redfield 1958) represents the average elemental composition of planktonic organisms, which can also be extended to trace element ratios (Quigg et al. 2003; Ho et al. 2004). Ratios of trace elements in the deep sea make an exception due to the adsorption onto particles (Morel 2008). The ratios of major nutrients in the ocean are similar to the Redfield ratio. Redfield (1958) hypothesized that this stoichiometric uniformity of plankton and major nutrients is controlled by phytoplankton. This is due to the fact that the ability of phytoplankton to fix carbon and nitrogen leaves an imprint on the oceanic stoichiometry during the remineralization of phytoplankton-derived organic matter. However, the stoichiometric ratio of phytoplankton varies across regions, seasons, and between different species, which leads to deviations from the Redfield ratio (Karl et al. 2001; Michaels et al. 2001). Inter- and intraspecific variations in the overall stoichiometry depend on the growth conditions, precisely the difference between the optimal ratio and the environmental conditions, to which the phytoplankton is actually exposed to (Hillebrand and Sommer 1999). Phytoplankton populations can, for example, produce and excrete carbon-rich 
DOM, which is depleted in nitrogen and phosphorus in relation to the original stoichiometry under nutrient limitation (Carlson et al. 1998; Hopkinson and Vallino 2005; Conan et al. 2007). Thus, the interaction between the given environmental conditions and cellular growth impact the stoichiometric ratio, which influences the bioreactivity and therefore the fate of the phytoplankton-derived organic matter during subsequent prokaryotic transformation processes (Azam and Malfatti 2007; Moreno and Martiny 2018).

\subsubsection{Prokaryotes and Viruses}

\subsubsection{Prokaryotes}

An estimated number of $10^{29}$ bacterial and archaeal cells reside ubiquitously in all habitats of the world's oceans (Whitman et al. 1998) and drive many of the underlying processes of the geochemical macro- and micronutrient cycles, by the remineralization or channeling of organic matter via the microbial loop (Azam et al. 1983). The chemical structure and abundance of organic matter, which is used as substrate and energy source by marine heterotrophic bacterioplankton, shape the prokaryotic community and its function in the respective ecosystem, from the nutrientdepleted pelagic ocean to nutrient-rich coastal regions and estuaries.

Copiotrophic bacteria (such as the classes Gammaproteobacteria, Flavobacteriia, and some Alphaproteobacteria) harbor a great genomic potential to react fast and efficient to short-term environmental changes and are well adapted to nutrient-rich environments (Lauro et al. 2009). This lifestyle is commonly found in lineages associated with phytoplankton bloom degradation, where different taxa are grown in substrate-controlled successions (see Sect. 15.3.1; Teeling et al. 2012, 2016). In contrast, oligotrophic bacteria (such as the SAR11- or SAR86-clusters) exhibit slower growth but are found in high relative abundances in the open ocean where nutrients are a limiting factor. Genomic streamlining and enzymatic adaption to low substrate concentration (Giovannoni et al. 2014) and therefore a more efficient use of resources give them a competitive advantage in low-nutrient environments (see Sect. 15.3.1). Since the establishment of the microbial loop concept by Azam et al. (1983), our understanding of the underlying prokaryotic processes has grown tremendously. Newly developed approaches to assess bacterial activity (Simon and Azam 1989; Pernthaler et al. 2002a; Alonso and Pernthaler 2005), community structure (Pernthaler et al. 2002b; Caporaso et al. 2012) and especially genetic and functional diversity (Tringe and Rubin 2005; Bashiardes et al. 2016) helped our understanding of how microbes biochemically shape the environment for millions of years (e.g., Canfield 2005). Yet metagenomics studies regularly reveal large amounts of unknown protein families (Sunagawa et al. 2015), suggesting a tremendous unexplored functional potential of microbes in the global oceans.

\subsubsection{Microbially Mediated Nutrient Cycling}

Many of the processes within the geochemical cycles have developed exclusively in bacteria or archaea and are performed by multiple species occupying a wide variety of ecological niches (DeLong et al. 1993; Sogin et al. 2006; Teeling et al. 2012). Biologically mediated nutrient cycling is carried out by enzymes catalyzing constrained redox reactions. These reactions are thermodynamically successive and involve identical or highly similar pathways that can be used as electron donor (oxidation) or electron acceptor (reduction) by different species (Falkowski et al. 2008). Dissimilatory processes are used by microorganisms to conserve energy, through oxidizing molecules leading to a net energy yield, which is released as heat or can be stored in ATP for later usage. In contrast, small molecules can also be reduced during assimilatory processes and used to build up complex molecules or biomass by using up chemical energy. For example, heterotrophic bacteria use the citric acid cycle to gain energy in form of ATP from the stepwise oxidation of acetate to carbon dioxide and water (Hederstedt 1993). The reverse reaction takes place under anoxic conditions, where phototrophic green sulfur bacteria grow by assimilating carbon dioxide in the same pathway under a net energy loss (Evans et al. 1966). Although substantial amounts of carbon are directly respired, up to two thirds are used for biomass production (Rivkin and Legendre 2001) and are thus available for further degradation within the microbial loop or for consumption by higher trophic levels. Only small amounts of carbon are channeled to the oceanic long-term carbon storage by either sinking, via the microbial carbon pump or by transformation to more resistant DOM (e.g., Volk and Hoffert 1985; Osterholz et al. 2015). In most cases, complete remineralization is temporally and spatially separated and is carried out by an array of diverse bacterial species. These different reaction steps are commonplace within biologically mediated geochemical cycling and can occur over large spatial distances (sea surface to deep sea) or in micro-gradients such as the phycosphere (Amin et al. 2012) or sinking particles (Alldredge and Cohen 1987). One of the many prokaryotic-mediated processes is the cycling of nitrogen in the oceans. Compounds containing nitrogen are essential for the synthesis of amino- and nucleic acids, yet the most abundant form of nitrogen, nitrogen gas, is highly inert and not bioavailable (see Sect. 15.2.1.1). Approximately, half of the global nitrogen fixation is carried out in the euphotic zone, mostly by cyanobacteria (e.g., Trichodesmium sp.), which transform nitrogen gas to ammonium (Fowler et al. 2013; Karl et al. 2002). Due to the extremely stable triple bond, the activation of nitrogen gas is a very energy- 
demanding reaction catalyzed by nitrogenases (Karl et al. 2002). This process is carried out in specialized cyanobacterial cells, called heterocysts. In these cells, the oxygen concentration is minimized by specific adaptations: thicker cell walls, the degradation of the photosynthesis apparatus, the upregulation of glycolytic processes, and specialized oxygen scavenging enzymes to prevent oxygen-induced enzyme damage to the nitrogenases (Gallon 1981). Ammonia itself is an essential part in the prokaryotic and eukaryotic biosynthesis of amino acids and is thus incorporated into biomass. Chemolithotrophic nitrifying bacteria (e.g., Nitrobacter sp., Nitrosomonas sp.) oxidize ammonium to nitrite and nitrate (Gruber 2008). Also archaea (e.g., the Crenarcheon Nitrosopumilus sp.) are found to catalyze these reactions (Könneke et al. 2005). In suboxic and anoxic environments (oxygen minimum zones or sediments), nitrate is reduced via a small number of intermediate products to nitrogen gas by denitrifying bacteria, thereby closing the marine nitrogen cycle (see Figs. 15.2 and 15.3). Additionally, some bacteria belonging to the Planctomycetes phylum are capable of direct oxidation of ammonium coupled to nitrite reduction, producing nitrogen gas via a hydrazine intermediate. Although the exact reaction mechanics are still under investigation, it is estimated that $30-50 \%$ of the nitrogen gas release by the oceans is produced by anammox bacteria (Devol 2003).

\subsubsection{Viruses}

Many publications about marine viruses emphasize that they are the most abundant biological entities in the marine environment (e.g., Wommack and Colwell 2000; Suttle 2007; Weynberg 2018). Viruses play a crucial role in controlling the composition of prokaryotic and phytoplankton populations, and as such shape and alter the function of marine food webs and global biogeochemical cycles (Weinbauer 2004; Short 2012; Weitz et al. 2015). By being ubiquitously distributed and the most abundant predatory agents in the sea, viruses ultimately control the diversity and biomass of their host populations (Thingstad 2000; Suttle 2007; Winter et al. 2010). The majority of marine viruses or phages is assumed to infect prokaryotic organisms (Fuhrman 1999; Suttle 2007; Breitbart 2011), removing approximately 5-40\% of the microbial standing stock on a daily basis (Suttle 2007; Middelboe 2008). These lytic phages can keep abundances of dominant prokaryotic species in balance, favoring less competitive species, thus maintaining the biodiversity of prokaryotic communities (Thingstad and Lignell 1997). Viruses also infect eukaryotic phytoplankton (e.g., Wilhelm and Suttle 1999; Brussaard 2004; Wilson et al. 2005), influencing the occurrence or the termination of bloom events (Bratbak et al. 1993).

The interaction between viruses and their hosts is, however, far more sophisticated than parasitism and predation
(Martiny et al. 2014). Viruses can confer new metabolic and morphological traits to their hosts through various mechanisms (Weinbauer and Rassoulzadegan 2004; Paul 2008; Rohwer and Thurber 2009; Hurwitz and U'Ren 2016), which may increase the fitness and, therefore, the survival of their hosts. This ultimately can impact the life history and evolution of the affected organisms (e.g., Sullivan et al. 2005).

Viruses also influence carbon, nutrient, and trace metal cycles. The production of viral progenies, through lytic infection, provokes lysis of the host cells, which results in the release of the cellular material into the environment. Within the viral shunt, most of the previously cell-bound DOM and POM can be readily recycled by noninfected prokaryotic communities or exported to the deep sea (Wilhelm and Suttle 1999; Middelboe and Lyck 2002; Weinbauer 2004). Approximately one quarter of the annual primary production in the ocean flows through the viral shunt and generates annually between 3 and $20 \mathrm{Gt}$ C (Wilhelm and Suttle 1999). By viral lysis, bio-limiting inorganic nutrients (e.g., phosphorus, ammonium) and other micronutrients, such as the organically complexed iron, are also regenerated and made available for the biologically utilization (Gobler et al. 1997; Poorvin et al. 2004; Shelford and Suttle 2018).

\subsection{Summary and Conclusion}

Both, biota and their chemical environment co-evolved over geological time periods, which led to sophisticated nets of mutual influence and dependence as outlined in this chapter. Autotrophic organisms require energy and inorganic electron donors to fix carbon dioxide for building up biomass, which in turn feeds the pool of DOM and POM. Without the work of heterotrophic organisms, however, the nonliving pools required by autotrophs would soon be exhausted. Thus, one compartment alone cannot be considered as the basis of marine life and cannot alone sufficiently explain the intertwined interactions within the ocean.

\footnotetext{
To understand the scope of ecology, the subjects must be considered in relation to other branches of biology and to 'ologies' in general. In the present age of specialization in human endeavors, the inevitable connections between different fields are often obscured by the large masses of knowledge within the fields. (Odum 1959)
}

As stated by Odum (1959), scientists run the risk of losing themselves in the details of their respective scientific discipline(s). An ecosystem can also be considered as a complex organism, such as the human body, where different organs are required to ensure its survival. Thus, also researchers should not just focus on their specific point of interest, but work together in multidisciplinary research approaches, such as doctors in hospitals, to unravel the complex network of an ecosystem. 
Authors Contribution $\mathrm{MH}$ and $\mathrm{CM}$ designed the concept of this review and contributed equally to the manuscript. $\mathrm{MH}$ wrote the virus, DOM and the phytoplankton section and parts of the introduction, while $\mathrm{CM}$ wrote the introduction, the inorganic matter section and conclusion. LD wrote the prokaryotes section.

\section{Appendix}

This article is related to the YOUMARES 9 conference session no. 18: "Crossing traditional scientific borders to unravel the complex interactions between organisms and their nonliving environment." The original Call for Abstracts and the abstracts of the presentations within this session can be found in the Appendix "Conference Sessions and Abstracts", Chapter "14 Crossing traditional scientific borders to unravel the complex interactions between organisms and their nonliving environment", of this book.

\section{References}

Aiken GR, Hsu-Kim H, Ryan JN (2011) Influence of dissolved organic matter on the environmental fate of metals, nanoparticles, and colloids. Environ Sci Technol 45:3196-3201

Alldredge AL, Cohen Y (1987) Can microscale chemical patches persist in the sea? Microelectrode study of marine snow, fecal pellets. Science 235:689-691

Alonso C, Pernthaler J (2005) Incorporation of glucose under anoxic conditions by bacterioplankton from coastal North Sea surface waters. Appl Environ Microbiol 71:1709-1716

Alonso-Sáez L, Sánchez O, Gasol JM (2012) Bacterial uptake of low molecular weight organic in the subtropical Atlantic: are major phylogenetic groups functionally different? Limnol Oceanogr 57:798-808

Aluwihare LI, Meador T (2008) Chapter 3 - Chemical composition of marine dissolved organic nitrogen. In: Capone DG, Bronk DA, Mulholland MR et al (eds) Nitrogen in the marine environment, 2nd edn. Academic Press, San Diego, pp 95-140

Amaro AM, Fuentes MS, Ogalde SR et al (2005) Identification and characterization of potentially algal-lytic marine bacteria strongly associated with the toxic dinoflagellate Alexandrium catenelly. J Eukaryot Microbiol 52:191-200

Amin SA, Parker MS, Armbrust EV (2012) Interactions between diatoms and bacteria. Microbiol Mol Biol Rev 76:667-684

Antoine D, Andre JM, Morel A (1996) Oceanic primary production. 2. Estimation at global scale from satellite (coastal zone color scanner) chlorophyll. Glob Biogeochem Cycles 10:57-69

Archer DE, Gidon E, Arne W et al (2000) Atmospheric $\mathrm{pCO}_{2}$ sensitivity to the biological pump in the ocean. Glob Biogeochem Cycles 14:1219-1230

Archer SD, Tarran GA, Stephens JA et al (2011) Combining cell sorting with gas chromatography to determine phytoplankton groupspecific intracellular dimethylsulphoniopropionate. Aquat Microb Ecol 62:109-121

Armbrust EV (2009) The life of diatoms in the world's oceans. Nature 459:185-192

Armstrong RA, Lee C, Hedges JI et al (2002) A new, mechanistic model for organic carbon fluxes in the ocean based on the quantitative association of POC with ballast minerals. Deep-Sea Res II 49:219-236
Arnosti C (2011) Microbial extracellular enzymes and the marine carbon cycle. Annu Rev Mar Sci 3:401-425

Arrieta JM, Mayol E, Hansman RL et al (2015) Dilution limits dissolved organic carbon utilization in the deep ocean. Science 348:331-333

Arrigo KR (2005) Marine microorganisms and global nutrient cycles. Nature 437:349

Azam F (1998) Microbial control of oceanic carbon flux: the plot thickens. Science 280:694-696

Azam F, Godson R (1977) Size distribution and activity of marine microheterotrophs. Limnol Oceanogr 22:492-501

Azam F, Malfatti F (2007) Microbial structuring of marine ecosystems. Nat Rev Microbiol 5:782-791

Azam F, Fenchel T, Field JG et al (1983) The ecological role of watercolumn microbes in the sea. Mar Ecol Prog Ser 10:257-263

Bashiardes S, Zilberman-Schapira G, Elinav E (2016) Use of metatranscriptomics in microbiome research. Bioinf Biol Insights 10:19-25

Bauer JE, Williams PM, Druffel ER (1992) ${ }^{14} \mathrm{C}$ activity of dissolved organic carbon fractions in the north-central Pacific and Sargasso Sea. Nature 357:667-670

Becker JW, Berube PM, Follett CL et al (2014) Closely related phytoplankton species produce similar suites of dissolved organic matter. Front Microbiol 5:111

Behrenfeld MJ (2010) Abandoning sverdrup's critical depth hypothesis on phytoplankton blooms. Ecology 91:977-989

Behrenfeld MJ, Falkowski PG (1997) Photosynthetic rates derived from satellite-based chlorophyll concentration. Limnol Oceanogr 42:1-20

Behrenfeld MJ, O'Malley RT, Siegel DA et al (2006) Climate-driven trends in contemporary ocean productivity. Nature 444:752-755

Benitez-Nelson CR (2000) The biogeochemical cycling of phosphorus in marine systems. Earth-Sci Rev 51:109-135

Benner R (2002) Chapter 3 - Chemical composition and reactivity. In: Hansell DA, Carlson CA (eds) Biogeochemistry of marine dissolved organic matter. Academic Press, San Diego, pp 59-90

Benner R, Biddanda B (1998) Photochemical transformations of surface and deep marine dissolved organic matter: effects on bacterial growth. Limnol Oceanogr 43:1373-1378

Bertrand EM, McCrow JP, Moustafa A et al (2015) Phytoplanktonbacterial interactions mediate micronutrient colimitation at the coastal Antarctic sea ice edge. Proc Natl Acad Sci U S A 112:9938-9943

Biddanda B, Benner R (1997) Carbon, nitrogen, and carbohydrate fluxes during the production of particulate and dissolved organic matter by marine phytoplankton. Limnol Oceanogr 42:506-518

Biller SJ, Berube PM, Lindell D et al (2015) Prochlorococcus: the structure and function of collective diversity. Nat Rev Microbiol $13: 13-27$

Billett DSM, Lampitt RS, Rice AL et al (1983) Seasonal sedimentation of phytoplankton to the deep-sea benthos. Nature 302:520-522

Bittar TB, Vieira AA, Stubbins A et al (2015) Competition between photochemical and biological degradation of dissolved organic matter from the cyanobacteria Microcystis aeruginosa. Limnol Oceanogr 60:1172-1194

Bjørrisen PK (1988) Phytoplankton exudation of organic-matter - why do healthy cells do it. Limnol Oceanogr 33:151-154

Boyd PW, Watson AJ, Law CS et al (2000) A mesoscale phytoplankton bloom in the polar Southern Ocean stimulated by iron fertilization. Nature 407:695-702

Boyd PW, Ellwood MJ, Tagliabue A et al (2017) Biotic and abiotic retention, recycling and remineralization of metals in the ocean. Nat Geosci 10:167-173

Bratbak G, Egge J, Heldal M (1993) Viral mortality of the marine alga Emiliania huxleyi (Haptophyceae) and termination of algal blooms. J Eukaryot Microbiol 93:39-48

Bratbak G, Wilson W, Heldal M (1996) Viral control of Emiliania huxleyi blooms? J Mar Syst 9:75-81 
Breitbart M (2011) Marine viruses: truth or dare. Annu Rev Mar Sci 4:425-448

Brown CW, Yoder JA (1994) Coccolithophorid blooms in the global ocean. J Geophys Res-Ocean 99:7467-7482

Bruland KW, Lohan MC (2003) Controls of trace metals in seawater. In: Elderfield $\mathrm{H}(\mathrm{ed})$ Treatise on geochemistry, vol 6. Elsevier, Amsterdam, pp 23-47

Bruland KW, Middag R, Lohan MC (2013) Controls of trace metals in seawater. In: Mittle MJ, Elderfield H (eds) Treatise on geochemistry, 2nd edn. Elsevier, Philadelphia, pp 19-51

Brussaard CPD (2004) Viral control of phytoplankton populations - a review. J Eukaryot Microbiol 51:125-138

Brzezinski MA, Phillips DR, Chavez FP et al (1997) Silica production in the Monterey, California, upwelling system. Limnol Oceanogr 42:1694-1705

Buchan A, LeCleir GR, Gulvik CA et al (2014) Master recyclers: features and functions of bacteria associated with phytoplankton blooms. Nat Rev Microbiol 12:686-698

Burdige DJ (1993) The biogeochemistry of manganese and iron reduction in marine sediments. Earth-Sci Rev 35:249-284

Callieri C (2017) Synechococcus plasticity under environmental changes. FEMS Microbiol Lett 364:fnx229

Canfield DE (2005) The early history of atmospheric oxygen: homage to Robert M. Garrels. Annu Rev Earth Planet Sci 33:1-36

Caporaso JG, Lauber CL, Walters WA et al (2012) Ultra-highthroughput microbia community analysis on the Illumina HiSeq and MiSeq platforms. ISME J 6:1621-1624

Carlson CA (2002) Production and removal processes. In: Hansell DA, Carlson CA (eds) Biogeochemistry of marine dissolved organic matter. Academic Press, San Diego, pp 91-151

Carlson CA, Ducklow HW, Hansell DA et al (1998) Organic carbon partitioning during spring phytoplankton blooms in the Ross Sea polynya and the Sargasso Sea. Limnol Oceanogr 43:375-386

Carlson CA, Giovannoni SJ, Hansell DA et al (2004) Interactions among dissolved organic carbon, microbial processes, and community structure in the mesopelagic zone of the northwestern Sargasso Sea. Limnol Oceanogr 49:1073-1083

Carlson CA, Del Giorgio PA, Herndl GJ (2007) Microbes and the dissipation of energy and respiration: from cells to ecosystems. Oceanography 20:89-100

Carritt DE (1954) Atmospheric pressure changes and gas solubility Deep-Sea Res 2:59-62

Chang FH, Zeldis J, Gall M et al (2003) Seasonal and spatial variation of phytoplankton assemblages, biomass and cell size from spring to summer across the north-eastern New Zealand continental shelf J Plankton Res 25:737-758

Chapman P (1986) Nutrient cycling in marine ecosystems. J Limnol Soc S Afr 12:22-42

Charlson RJ, Lovelock JE, Andreae MO et al (1987) Oceanic phytoplankton, atmospheric sulfur, cloud albedo and climate. Nature 326:655-661

Chavez FP, Messié M, Pennington JT (2011) Marine primary production in relation to climate variability and change. Annu Rev Mar Sci 3:227-260

Chester R, Jickells T (2012) Marine geochemistry. Wiley, Chichester

Chisholm SW (1992) Phytoplankton size. In: Falkowski PG, Woodhead $\mathrm{AD}$, Vivirito $\mathrm{K}$ (eds) Primary productivity and biogeochemical cycles in the sea. Springer US, Boston, pp 213-237

Cloern JE (1996) Phytoplankton bloom dynamics in coastal ecosystems: a review with some general lessons from sustained investigation of San Francisco Bay, California. Rev Geophys 34:127-168

Cloern JE, Dufford R (2005) Phytoplankton community ecology: principles applied in San Francisco Bay. Mar Ecol Prog Ser 285:11-28

Cloern JE, Jassby AD (2010) Patterns and scales of phytoplankton variability in estuarine-coastal ecosystems. Estuar Coast 33:230-241
Cole JJ, Findlay S, Pace ML (1988) Bacterial production in fresh and saltwater ecosystems - a cross-system overview. Mar Ecol Prog Ser 43:1-10

Conan P, Sondergaard M, Kragh T et al (2007) Partitioning of organic production in marine plankton communities: the effects of inorganic nutrient ratios and community composition on new dissolved organic matter. Limnol Oceanogr 52:753-765

Conley DJ, Schelske CL, Stoermer EF (1993) Modification of the biogeochemical cycle of silica with eutrophication. Mar Ecol Prog Ser 101:179-192

Cotner JB, Wetzel RG (1992) Uptake of dissolved inorganic and organic phosphorus compounds by phytoplankton and bacterioplankton. Limnol Oceanogr 37:232-243

Cude WN, Mooney J, Tavanaei AA et al (2012) Production of the antimicrobial secondary metabolite indigoidine contributes to competitive surface colonization by the marine roseobacter Phaeobacter sp. strain Y4I. Appl Environ Microbiol 78:4771-4780

Danger M, Leflaive J, Oumarou C et al (2007) Control of phytoplankton-bacteria interactions by stoichiometric constraints. Oikos 116:1079-1086

DeLong EF, Franks DG, Alldredge AL (1993) Phylogenetic diversity of aggregate-attached vs. free-living marine bacterial assemblages. Limnol Oceanogr 38:924-934

Devol AH (2003) Nitrogen cycle: solution to a marine mystery. Nature 422:575

Dittmar T (2015) Chapter 7 - Reasons behind the long-term stability of dissolved organic matter. In: Hansell DA, Carlson CA (eds) Biogeochemistry of marine dissolved organic matter. Academic Press, San Diego, pp 369-388

Dittmar T, Paeng J (2009) A heat-induced molecular signature in marine dissolved organic matter. Nat Geosci 2:175-179

Dittmar T, Stubbins A (2014) Dissolved organic matter in aquatic systems. In: Birrer B, Falkowski P, Freemann K (eds) Treatise of geochemistry, 2nd edn. Elsevier, Oxford, pp 125-156

Dobson M, Frid C (2008) Ecology of aquatic systems. Oxford University Press, Oxford

Druffel ERM, Bauer JE, Williams PM et al (1996) Seasonal variability of particulate organic radiocarbon in the northeast Pacific ocean. J Geophys Res-Oceans 101:20543-20552

Ducklow HW, Kirchman DL, Quinby HL et al (1993) Stocks and dynamics of bacterioplankton carbon during the spring bloom in the eastern North Atlantic Ocean. Deep-Sea Res Pt II 40:245-263

Dyhrman ST, Ammerman JW, van Mooy BAS (2007) Microbes and the marine phosphorus cycle. Oceanography 20:110-116

Egge JK, Aksnes DL (1992) Silicate as regulating nutrient in phytoplankton competition. Mar Ecol Prog Ser 83:281-289

Elser JJ, Hassett RP (1994) A stoichiometric analysis of the zooplankton-phytoplankton interaction in marine and freshwater ecosystems. Nature 370:211-213

Eppley RW, Peterson BJ (1979) Particulate organic-matter flux and planktonic new production in the deep ocean. Nature 282:677-680

Evans M, Buchanan BB, Arnon DI (1966) A new ferredoxin-dependent carbon reduction cycle in a photosynthetic bacterium. Proc Natl Acad Sci USA 55:928-934

Falkowski PG, Raven R (2007) Aquatic photosynthesis. Princeton University Press, Princeton

Falkowski PG, Barber RT, Smetacek V (1998) Biogeochemical controls and feedbacks on ocean primary production. Science 281:200-206

Falkowski PG, Fenchel T, Delong EF (2008) The microbial engines that drive Earth's biogeochemical cycles. Science 320:1034-1039

Fiedler PC, Talley LD (2006) Hydrography of the eastern tropical Pacific: a review. Prog Oceanogr 69:143-180

Field CB, Behrenfeld MJ, Randerson JT et al (1998) Primary production of the biosphere: integrating terrestrial and oceanic components. Science 281:237-240 
First MR, Hollibaugh JT (2009) The model high molecular weight DOC compound, dextran, is ingested by the benthic ciliate Uronema marinum but does not supplement ciliate growth. Aquat Microb Ecol 57:79-87

Fleming RH (1940) The composition of plankton and units for reporting population and production. Proc Pacif Sci Congr 3:535-540

Flombaum P, Gallegos JL, Gordillo RA et al (2013) Present and future global distributions of the marine Cyanobacteria Prochlorococcus and Synechococcus. Proc Natl Acad Sci USA 110:9824-9829

Flynn KJ, Stocker DK, Mitra A et al (2013) Misuse of the phytoplanktonzooplankton dichotomy: the need to assign organisms as mixotrophs within plankton functional types. J Plankton Res 35:3-11

Fogg GE, Nalewajko C, Watt WD (1965) Extracellular products of phytoplankton photosynthesis. Proc R Soc B Biol Sci 162:517-534

Foster RA, Kuypers MMM, Vagner T et al (2011) Nitrogen fixation and transfer in open ocean diatom-cyanobacterial symbiosis. ISME J 5:1484-1493

Fowler D, Coyle M, Skiba U et al (2013) The global nitrogen cycle in the twenty-first century. Philos Trans R Soc B 368:20130164

Francis CA, Tebo BM (2001) cumA multicopper oxidase genes from diverse $\mathrm{Mn}(\mathrm{II})$-oxidizing and non-Mn(II)-oxidizing Pseudomonas strains. Appl Environ Microbiol 67:4272-4278

Fuhrman JA (1999) Marine viruses and their biogeochemical and ecological effects. Nature 399:541-548

Fuhrman JA, McCallum K, Davis AA (1992) Novel major archaebacterial group from marine plankton. Nature 356:148-149

Fuhrman JA, Steele JA, Hewson I et al (2008) A latitudinal diversity gradient in planktonic marine bacteria. Proc Natl Acad Sci USA 105:7774-7778

Gallon JR (1981) The oxygen sensitivity of nitrogenase: a problem for biochemists and micro-organisms. Trends Biochem Sci 6:19-23

Giovannoni SJ, Thrash JC, Temperton B (2014) Implications of streamlining theory for microbial ecology. ISME J 8:1553-1565

Gobler CJ, Hutchins DA, Fisher NS et al (1997) Release and bioavailability of C, N, P Se, and Fe following viral lysis of a marine chrysophyte. Limnol Oceanogr 42:1492-1504

Gonsior M, Hertkorn N, Conte MH et al (2014) Photochemical production of polyols arising from significant photo-transformation of dissolved organic matter in the oligotrophic surface ocean. Mar Chem 163:10-18

Grossart HP, Czub G, Simon M (2006) Algae-bacteria interactions and their effects on aggregation and organic matter flux in the sea. Environ Microbiol 8:1074-1084

Gruber N (2008) Chapter 1 - The marine nitrogen cycle: overview and challenges. In: Capone DG, Bronk DA, Mulholland MR et al (eds) Nitrogen in the marine environment, 2nd edn. Academic Press, San Diego, pp 1-50

Guidi L, Chaffron S, Bittner L et al (2016) Plankton networks driving carbon export in the oligotrophic ocean. Nature 532:465-470

Hansell DA (2013) Recalcitrant dissolved organic carbon fractions. Annu Rev Mar Sci 5:421-445

Hansell DA, Carlson CA (2001) Marine dissolved organic matter and the carbon cycle. Oceanography 14:41-49

Hansell DA, Carlson CA (2013) Localized refractory dissolved organic carbon sinks in the deep ocean. Global Biogeochem Cycles 27:705-710

Hansell DA, Carlson CA, Repeta DJ et al (2009) Dissolved organic matter in the ocean a controversy stimulates new insights. Oceanography 22:202-211

Hansell DA, Carlson CA, Schlitzer R (2012) Net removal of major marine dissolved organic carbon fractions in the subsurface ocean. Global Biogeochem Cycles 26:GB1016

Hawkes JA, Rossel PE, Stubbins A et al (2015) Deep-ocean dissolved organic matter in hydrothermal vents. Nat Geosci 8:856-860
Hederstedt L (1993) The Krebs citric acid cycle. In: Sonenshein A, Hoch J, Losick R (eds) Bacillus subtilis and other gram-positive bacteria. ASM Press, Washington, DC, pp 181-197

Hedges JI (1992) Global biogeochemical cycles: progress and problems. Mar Chem 39:67-93

Heisler J, Glibert PM, Burkholder JM et al (2008) Eutrophication and harmful algal blooms: a scientific consensus. Harmful Algae $8: 3-13$

Hertkorn N, Harir M, Koch BP et al (2013) High-field NMR spectroscopy and FT-ICR mass spectrometry: powerful discovery tools for the molecular level characterization of marine dissolved organic matter. Biogeosciences 10:1583-1624

Hillebrand H, Sommer U (1999) The nutrient stoichiometry of benthic microalgal growth: redfield proportions are optimal. Limnol Oceanogr 44:440-446

Hjuler ML, Fabricius IL (2009) Engineering properties of chalk related to diagenetic variations of Upper Cretaceous onshore and offshore chalk in the North Sea area. J Pet Sci Eng 68:151-170

Ho TY, Quigg A, Finkel Z et al (2004) The elemental composition of some marine phytoplankton. J Phycol 39:1145-1159

Hopkinson CS Jr, Vallino JJ (2005) Efficient export of carbon to the deep ocean through dissolved organic matter. Nature 433:142-145

Hünken M, Harder J, Kirst GO (2008) Epiphytic bacteria on the Antarctic ice diatom Amphiprora kufferathii Manguin cleave hydrogen peroxide produced during algal photosynthesis. Plant Biol 10:519-526

Hurwitz BL, U'Ren JM (2016) Viral metabolic reprogramming in marine ecosystems. Curr Opin Microbiol 31:161-168

Hutchins DA, Witter AE, Butler A et al (1999) Competition among marine phytoplankton for different chelated iron species. Nature 400:858-861

Jiao N, Herndl GJ, Hansell DA et al (2010) Microbial production of recalcitrant dissolved organic matter: long-term carbon storage in the global ocean. Nat Rev Microbiol 2010:593-599

Kahru M, Brotas V, Manzano-Sarabia M et al (2011) Are phytoplankton blooms occurring earlier in the Arctic? Glob Chang Biol 17:1733-1739

Karl DM, Bjoerkman K, Dore EJ et al (2001) Ecological nitrogento-phosphorus stoichiometry at Station ALOHA. Deep-Sea Res II 48:1529-1566

Karl DM, Michaels A, Bergman B et al (2002) Dinitrogen fixation in the world's oceans. In: Boyer EW, Howarth RW (eds) The nitrogen cycle at regional to global scales. Springer, Dordrecht, pp 47-98

Karner MB, DeLong EF, Karl DM (2001) Archaeal dominance in the mesopelagic zone of the Pacific Ocean. Nature 409:507-510

Kastner M, Keene JB, Gieskes JM (1977) Diagenesis of siliceous oozes. Chemical controls on the rate of opal-A to opal-CT transformationan experimental study. Geochim Cosmochim Acta 41:1041-1059

Kazamia E, Czesnick H, Nguyen TT et al (2012) Mutualistic interactions between vitamin B12-dependent algae and heterotrophic bacteria exhibit regulation. Environ Microbiol 14:1466-1476

Kieber DJ, McDaniel J, Mopper K (1989) Photochemical source of biological substrates in sea-water - implications for carbon cycling. Nature 341:637-639

Kieber DJ, Keene WC, Frossard AA et al (2016) Coupled oceanatmosphere loss of marine refractory dissolved organic carbon. Geophys Res Lett 43:2765-2772

Koch BP, Witt MR, Engbrodt R et al (2005) Molecular formulae of marine and terrigenous dissolved organic matter detected by electrospray ionization Fourier transform ion cyclotron resonance mass spectrometry. Geochim Cosmochim Acta 69:3399-3308

Könneke M, Bernhard AE, de la Torre JR et al (2005) Isolation of an autotrophic ammonia-oxidizing marine archaeon. Nature 437:543-546 
Kovarova-Kovar K, Egli T (1998) Growth kinetics of suspended microbial cells: from single-substrate-controlled growth to mixedsubstrate kinetics. Microbiol Mol Biol Rev 62:646-666

Kujawinksi EB, Longnecker K, Barott KL et al (2016) Microbial community structure affects marine dissolved organic matter composition. Front Mar Sci 3:45

Kujawinski EB (2011) The impact of microbial metabolism on marine dissolved organic matter. Annu Rev Mar Sci 3:567-599

Landa M, Blain S, Christaki U et al (2016) Shifts in bacterial community composition associated with increased carbon cycling in a mosaic of phytoplankton blooms. ISME J 10:39-50

Landry MR, Kirchman DL (2002) Microbial community structure and variability in the tropical Pacific. Deep-Sea Res II 49:2669-2693

Lang SQ, Butterfield DA, Lilley MD et al (2006) Dissolved organic carbon in ridge-axis and ridge-flank hydrothermal systems. Geochim Cosmochim Acta 70:3830-3842

LaRowe DE, Dale AW, Amend JP et al (2012) Thermodynamic limitations on microbially catalyzed reaction rates. Geochim Cosmochim Acta 90:96-109

Lauro FM, McDougald D, Thomas T et al (2009) The genomic basis of trophic strategy in marine bacteria. Proc Natl Acad Sci USA 106:15527-15533

Lechtenfeld OJ, Hertkorn N, Shen Y et al (2015) Marine sequestration of carbon in bacterial metabolites. Nat Commun 6:6711

Lessard E, Merico A, Tyrrell T (2005) Nitrate: phosphate ratios and Emiliania huxleyi blooms. Limnol Oceanogr 50:1020-1024

Lima-Mendez G, Faust K, Henry N et al (2015) Top-down determinants of communitiy structure in the global plankton interactome. Science 348:6237

Liss P, Malin G, Turner SM et al (1994) Dimethyl sulphide and Phaeocystis: a review. J Mar Sci 5:41-53

Litchman E, Klausmeier CA, Miller JR et al (2006) Multi-nutrient, multi-group model of present and future oceanic phytoplankton communities. Biogeosciences 3:585-606

Loeder M, Meunier C, Wiltshire K et al (2011) The role of ciliates, heterotrophic dinoflagellates and copepods in structuring spring plankton communities at Helgoland Roads, North Sea. Mar Biol 158:1551-1580

Logue JB, Stedmon CA, Kellerman AM et al (2016) Experimental insights into the importance of aquatic bacterial community composition to the degradation of dissolved organic matter. ISME J 10:533-545

Longhurst A, Sathyendranath S, Platt T et al (1995) An estimate of global primary production in the ocean from satellite radiometer data. J Plankton Res 17:1245-1271

Longnecker K, Kido Soule MC, Kujawinski EB (2015) Dissolved organic matter produced by Thalassiosira pseudonana. Mar Chem 168:114-123

Mague TH, Friberg E, Hughes DJ et al (1980) Extracellular release of carbon by marine phytoplankton - a physiological approach. Limnol Oceanogr 25:262-279

Maldonado MT, Price NM (2001) Reduction and transport of organically bound iron by Thalassiosira oceanica (Bacillariophyceae). J Phycol 37:298-310

Maranon E, Cermeno P, Perez V (2005) Continuity in the photosynthetic production of dissolved organic carbon from eutrophic to oligotrophic waters. Mar Ecol Prog Ser 299:7-17

Martin MO (2002) Predatory prokaryotes: an emerging research opportunity. J Mol Microb Biotechnol 4:467-477

Martiny JB, Riemann L, Marston MF et al (2014) Antagonistic coevolution of marine planktonic viruses and their hosts. Annu Rev Mar Sci 6:393-414

Medeiros PM, Seidel M, Powers LC et al (2015a) Dissolved organic matter composition and photochemical transformations in the northern North Pacific Ocean. Geophys Res Lett 42:863-870
Medeiros PM, Seidel M, Ward ND et al (2015b) Fate of the Amazon River dissolved organic matter in the tropical Atlantic Ocean. Global Biogeochem Cycles 29:677-690

Metaxas A, Scheibling R (1996) Top-down and bottom-up regulation of phytoplankton assemblages in tidepools. Mar Ecol Prog Ser 145:161-177

Michaels A, Karl DM, Capone D (2001) Element stoichiometry, new production and nitrogen fixation. Oceanography 14:68-77

Michelou VK, Cottrell MT, Kirchman DL (2007) Light-stimulated bacterial production and amino acid assimilation by cyanobacteria and other microbes in the North Atlantic Ocean. Appl Environ Microbiol 73:5539-5546

Middelboe M (2008) Microbial disease in the sea: effects of viruses on carbon and nutrient cycling Infections Disease Ecology. Princeton University Press, Princeton, pp 242-260

Middelboe M, Lyck PG (2002) Regeneration of dissolved organic matter by viral lysis in marine microbial communities. Aquat Microb Ecol 27:187-194

Moffett JW, Brand LE (1996) Production of strong, extracellular $\mathrm{Cu}$ chelators by marine cyanobacteria in response to $\mathrm{Cu}$ stress. Limnol Oceanogr 41:388-395

Moore WS (2010) The effect of submarine groundwater discharge on the ocean. Annu Rev Mar Sci 2:59-88

Moore LR, Goericke R, Chisholm SW (1995) Comparative physiology of Synechococcus and Prochlorococcus: influence of light and temperature on growth, pigments, fluorescence and absorptive properties. Mar Ecol Prog Ser 116:259-275

Mopper K, Zhou XL, Kieber RJ et al (1991) Photochemical degradation of dissolved organic carbon and its impact on the oceanic carbon cycle. Nature 353:60-62

Moran MA, Reisch C, Kiene R et al (2012) Genomic insights into bacterial DMSP transformations. Annu Rev Mar Sci 4:523-542

Morel FMM (1986) Trace metals - phytoplankton interactions: an overview. Elsev Oceanogr Serie 43:177-189

Morel FMM (2008) The co-evolution of phytoplankton and trace element cycles in the oceans. Geobiology 6:318-324

Morel FMM, Price N (2003) The biogeochemical cycles of trace metals in the oceans. Science 300:944-947

Moreno AR, Martiny AC (2018) Ecological stoichiometry of ocean plankton. Annu Rev Mar Sci 10:43-69

Myklestad SM (1974) Production of carbohydrates by marine planktonic diatoms. 1. Comparison of 9 different species in culture. J Exp Mar Biol Ecol 15:261-274

Myklestad SM (2000) Dissolved organic carbon from phytoplankton. In: Wangersky PJ (ed) Marine chemistry. Springer, Berlin, pp 111-148

Nagata T, Kirchman D (1992) Release of dissolved organic matter by heterotrophic protozoa: Implications for microbial food webs. Arch Hydrobiol 35:99-109

Nelson DM, Tréguer P, Brzezinski A et al (1995) Production and dissolution of biogenic silica in the ocean: revised global estimates, comparison with regional data and relationship to biogenic sedimentation. Global Biogeochem Cycles 9:359-732

Nicholson D, Dyhrman S, Chavez F et al (2006) Alkaline phosphatase activity in the phytoplankton communities of Monterey Bay and San Francisco Bay. Limnol Oceanogr 51:874-883

Odum EP (1959) Fundamentals of ecology, vol 2. WB Saunders Company, Philadelphia

Ogawa H, Tanoue E (2003) Dissolved organic matter in oceanic waters. J Oceanogr 59:129-147

Ogawa H, Amagai Y, Koike I et al (2001) Production of refractory dissolved organic matter by bacteria. Science 292:917-920

Osterholz H, Niggemann J, Giebel H-A et al (2015) Inefficient microbial production of refractory dissolved organic matter in the ocean. Nat Commun 6:7422 
Partensky F, Blanchot J, Vaulot D (1999) Differential distribution and ecology of Prochlorococcus and Synechococcus in oceanic waters: a review. In: Loic C, Larkum AWD (eds) Marine cyanobacteria, Bulletin-Insitut Oceanographique de Monaco, Paris, pp 457-475

Passow U (2002) Production of transparent exopolymer particles (TEP) by phyto-and bacterioplankton. Mar Ecol Prog Ser 236:1-12

Paul JH (2008) Prophages in marine bacteria: dangerous molecular time bombs or the key to survival in the seas? ISME J 2:579-589

Paytan A, McLaughlin K (2007) The oceanic phosphorus cycle. Chem Rev 107:563-576

Pennington JT, Mahoney KL, Kuwahara VS et al (2006) Primary production in the eastern tropical Pacific: a review. Prog Oceanogr 69:285-317

Pernthaler A, Pernthaler J, Amann R (2002a) Fluorescence in situ hybridization and catalyzed reporter deposition for the identification of marine bacteria. Appl Environ Microbiol 68:3094-3101

Pernthaler A, Pernthaler J, Schattenhofer M et al (2002b) Identification of DNA-synthesizing bacterial cells in coastal North Sea plankton. Appl Environ Microbiol 68:5728-5736

Pomeroy LR (1974) The ocean's food web, a changing paradigm. Bioscience 24:499-504

Pomeroy LR, Williams PJ, Azam F et al (2007) The microbial loop. Oceanography 20:28-33

Poorvin L, Rinta-Kanto JM, Hutchins DA et al (2004) Viral release of iron and its bioavailability to marine plankton. Limnol Oceanogr 49:1734-1741

Quigg A, Finkel Z, Irwin A et al (2003) The evolutionary inheritance of elemental stoichiometry in marine phytoplankton. Nature 425:291-294

Ragueneau O, Tréguer P, Leynaert A et al (2000) A review of the Si cycle in the modern ocean: recent progress and missing gaps in the application of biogenic opal as a paleoproductivity proxy. Glob Planet Chang 26:317-365

Redfield AC (1958) The biological control of chemical factors in the environment. Am Sci 46:205-221

Redfield AC, Ketchum BH, Richards FA (1963) The Influence of organisms on the composition of sea-water. In: Hill MN (ed) The composition of seawater: comparative and descriptive oceanography. The sea: ideas and observations on progress in the study of the sea, vol 2. Wiley Interscience, New York, p 26-77

Repeta DJ (2015) Chapter 2 - Chemical characterization and cycling of dissolved organic matter. In: Hansell DA, Carlson CA (eds) Biogeochemistry of marine dissolved organic matter, 2nd edn. Academic Press, Boston, pp 21-63

Reynolds CS (1984) The ecology of freshwater phytoplankton. Cambridge University Press, Cambridge

Reynolds CS (2006) Ecology of phytoplankton. Cambridge University Press, Cambridge

Riebesell U (1991) Particle aggregation during a diatom bloom. II. Biological aspects. Mar Ecol Prog Ser 69:281-291

Riemann L, Steward G, Azam F (2000) Dynamics of bacterial community composition and activity during a mesocosm diatom bloom. Appl Environ Microbiol 66:578-587

Rink B, Seeberger S, Martens T et al (2007) Effects of phytoplankton bloom in a coastal ecosystem on the composition of bacterial communities. Aquat Microb Ecol 48:47-60

Rivkin RB, Legendre L (2001) Biogenic carbon cycling in the upper ocean: effects of microbial respiration. Science 291:2398-2400

Rohwer F, Thurber RV (2009) Viruses manipulate the marine environment. Nature 459:207-212

Rossel PE, Vähätalo AV, Witt M et al (2013) Molecular composition of dissolved organic matter from a wetland plant (Juncus effusus) after photochemical and microbial decomposition (1.25 years): common features with deep sea dissolved organic matter. Org Geochem 60:62-71
Rossel PE, Stubbins A, Hach P et al (2015) Bioavailability and molecular composition of dissolved organic matter from a diffuse hydrothermal system. Mar Chem 177:257-266

Ruttenberg KC, Berner RA (1993) Authigenic apatite formation and burial in sediments from non-upwelling, continental margin environments. Geochim Cosmochim Acta 57:991-1007

Saito MA, Moffett JW, Chisholm SW et al (2002) Cobalt limitation and uptake in Prochlorococcus. Limnol Oceanogr 47:1629-1636

Schoemann V, Becquevort S, Stefels J et al (2005) Phaeocystis blooms in the global ocean and their controlling mechanisms: a review. J Sea Res 53:43-66

Seyedsayamdost MR, Case RJ, Kolter R et al (2011) The Jekyll-andHyde chemistry of Phaeobacter gallaeciensis. Nat Chem 3:331-335

Seymour JR, Amin SA, Raina JB et al (2017) Zooming in on the phycosphere: the ecological interface for phytoplankton-bacteria relationships. Nat Microbiol 30:17065

Shelford EJ, Suttle CA (2018) Virus-mediated transfer of nitrogen from heterotrophic bacteria to phytoplankton. Biogeosciences $15: 809-819$

Short SM (2012) The ecology of viruses that infect eukaryotic algae. Environ Microbiol 14:2253-2271

Siegenthaler U, Sarmiento J (1993) Atmospheric carbon dioxide and the ocean. Nature 365:119-125

Simon M, Azam F (1989) Protein content and protein synthesis rates of planktonic marine bacteria. Mar Ecol Prog Ser 51:201-213

Simon N, Cras AL, Foulon E et al (2009) Diversity and evolution of marine phytoplankton. C R Biol 332:159-170

Smayda TJ (1997) Harmful algal blooms: their ecophysiology and general relevance to phytoplankton blooms in the sea. Limnol Oceanogr 42:1137-1153

Smayda TJ, Reynolds CS (2003) Strategies of marine dinoflagellate survival and some rules of assembly. J Sea Res 49:95-106

Smetacek V (1985) Role of sinking in diatom life-history cycles: ecological, evolutionary and geological significance. Mar Biol 84:239-251

Smetacek V (1999) Diatoms and the ocean carbon cycle. Protist 150:25-32

Smetacek V, Cloern J (2008) Oceans - on phytoplankton trends. Science 319:1346-1348

Smith DC, Simon M, Alldredge AL et al (1992) Intense hydrolytic enzyme-activity on marine aggregates and implications for rapid particle dissolution. Nature 359:139-142

Sogin ML, Morrison HG, Huber JA et al (2006) Microbial diversity in the deep sea and the underexplored "rare biosphere". Proc Natl Acad Sci USA 103:12115-12120

Solomon S, Qin D, Manning M et al (2007) Climate change 2007the physical science basis: working group I contribution to the fourth assessment report of the IPCC. Cambridge University Press, New York

Sommer U, Lengfellner K (2008) Climate change and the timing, magnitude, and composition of the phytoplankton spring blooms. Glob Change Biol 14:1199-1208

Søreide JE, Leu E, Berge J et al (2010) Timing of blooms, algal food quality and Calanus glacialis reproduction and growth in a changing Arctic. Glob Change Biol 16:3154-3163

Sournia A, Chrdtiennot-Dinet MJ, Ricard M (1991) Marine phytoplankton: how many species in the world ocean? J Plankton Res 13:1093-1099

Stocker R (2012) Marine microbes see a sea of gradients. Science 338:628-633

Stubbins A, Spencer RGM, Chen H et al (2010) Illuminated darkness: molecular signatures of Congo River dissolved organic matter and its photochemical alteration as revealed by ultrahigh precision mass spectrometry. Limnol Oceanogr 55:1467-1477 
Sullivan MB, Coleman ML, Weigele $P$ et al (2005) Three Prochlorococcus cyanophage genomes: signature features and ecological interpretations. PLoS Biol 3:e144

Sunagawa S, Coelho LP, Chaffron S et al (2015) Structure and function of the global ocean microbiome. Science 348:261359

Sunda WG (1989) Trace metal interactions with marine phytoplankton. Biol Oceanogr 6:411-442

Sunda WG (1994) Trace metal/phytoplankton interactions in the sea. In: Bidoglio G, Stumm W (eds) Chemistry of aquatic systems: local and global perspectives. Springer, Dordrecht, pp 213-247

Sunda WG (2012) Feedback interactions between trace metal nutrients and phytoplankton in the ocean. Front Microbiol 3:204

Suttle CA (2007) Marine viruses-major players in the global ecosystem. Nat Rev Microbiol 5:801-812

Taylor JR, Ferrari R (2011) Shutdown of turbulent convection as a new criterion for the onset of spring phytoplankton blooms. Limnol Oceanogr 56:2293-2307

Tebo BM, Bargar JR, Clement BG et al (2004) Biogenic manganese oxides: properties and mechanisms of formation. Annu Rev Earth Planet Sci 32:287-328

Teeling H, Fuchs BM, Becher D et al (2012) Substrate-controlled succession of marine bacterioplankton populations induced by a phytoplankton bloom. Science 336:608-611

Teeling H, Fuchs BM, Bennke CM et al (2016) Recurring patterns in bacterioplankton dynamics during coastal spring algae blooms. elife 5:e11888

Thingstad TF (2000) Elements of a theory for the mechanisms controlling abundance, diversity, and biogeochemical role of lytic bacterial viruses in aquatic systems. Limnol Oceanogr 45:1320-1328

Thingstad TF, Lignell R (1997) Theoretical models for the control of bacterial growth rate, abundance, diversity and carbon demand. Aquat Microb Ecol 13:19-27

Thornton DCO (2014) Dissolved organic matter (DOM) release by phytoplankton in the contemporary and future ocean. Eur J Phycol 49:20-46

Tringe SG, Rubin EM (2005) Metagenomics: DNA sequencing of environmental samples. Nat Rev Genet 6:805-814

Twining BS, Baines SB (2013) The trace metal composition of marine phytoplankton. Annu Rev Mar Sci 5:191-215

Volk T, Hoffert MI (1985) Ocean carbon pumps: Analysis of relative strengths and efficiencies in ocean driven atmospheric $\mathrm{CO}_{2}$ changes. Geophys Monogr Ser 32:99-110
Weinbauer MG (2004) Ecology of prokaryotic viruses. FEMS Microbiol Rev 28:127-181

Weinbauer MG, Rassoulzadegan F (2004) Are viruses driving microbial diversification and diversity? Environ Microbiol 6:1-11

Weiss MS, Abele U, Weckesser J et al (1991) Molecular architecture and electrostatic properties of a bacterial porin. Science 254:1627-1630

Weitz JS, Stock CA, Wilhelm SW et al (2015) A multitrophic model to quantify the effects of marine viruses on microbial food webs and ecosystem processes. ISME J 9:1352-1364

Westbroek P, Young JR, Linschooten K (1989) Coccolith production (biomineralization) in the marine alga Emiliania huxleyi. J Protozool 36:368-373

Wetz MS, Wheeler PA (2007) Release of dissolved organic matter by coastal diatoms. Limnol Oceanogr 52:798-807

Weynberg KD (2018) Viruses in marine ecosystems: From open waters to coral reefs. Adv Virus Res 101:1-38

Whitman WB, Coleman DC, Wiebe WJ (1998) Prokaryotes: the unseen majority. Proc Natl Acad Sci USA 95:6578-6583

Wilhelm SW, Suttle CA (1999) Viruses and nutrient cycles in the sea: viruses play critical roles in the structure and function of aquatic food webs. Bioscience 49:781-788

Williams PM, Druffel ERM (1987) Radiocarbon in dissolven organicmatter in the central North Pacific Ocean. Nature 330:246-248

Williams LA, Parks GA, Crerar DA (1985) Silica diagenesis. Solubility controls. J Sediment Res 55:301-311

Wilson WH, Schroeder DC, Allen MJ et al (2005) Complete genome sequence and lytic phase transcription profile of a Coccolithovirus. Science 309:1090-1092

Winter C, Bouvier T, Weinbauer MG et al (2010) Trade-offs between competition and defense specialists among unicellular planktonic organisms: the 'killing the winnter' hypothesis revisited. Microbiol Mol Biol Rev 74:42-57

Wommack KE, Colwell RR (2000) Virioplankton: viruses in aquatic ecosystems. Microbiol Mol Biol Rev 64:69-114

Yager P, Connelly T, Mortazavi B et al (2001) Dynamic bacterial and viral response to an algal bloom at subzero temperatures. Limnol Oceanogr 46:90-801

Zark M, Christoffers J, Dittmar T (2017) Molecular properties of deep-sea dissolved organic matter are predictable by the central limit theorem: evidence from tandem FT-ICR-MS. Mar Chem 191:9-15

Open Access This chapter is licensed under the terms of the Creative Commons Attribution 4.0 International License (http://creativecommons. org/licenses/by/4.0/), which permits use, sharing, adaptation, distribution and reproduction in any medium or format, as long as you give appropriate credit to the original author(s) and the source, provide a link to the Creative Commons license and indicate if changes were made.

The images or other third party material in this chapter are included in the chapter's Creative Commons license, unless indicated otherwise in a credit line to the material. If material is not included in the chapter's Creative Commons license and your intended use is not permitted by statutory regulation or exceeds the permitted use, you will need to obtain permission directly from the copyright holder. 